\title{
Mechanistic insights into catalytic linear cross-dimerization between conjugated dienes and styrenes by a ruthenium( 0 ) complex
}

\author{
Masafumi Hirano, ${ }^{a, b}$ Takao Ueda, ${ }^{a}$ Nobuyuki Komine, ${ }^{a}$ Sanshiro Komiya, ${ }^{a, \ddagger}$ Saki Nakamura, ${ }^{c}$ \\ Hikaru Deguchi, ${ }^{c}$ Susumu Kawauchi*b,c
}

${ }^{a}$ Department of Applied Chemistry, Graduate School of Engineering, Tokyo University of Agriculture and Technology, 2-24-16 Nakacho, Koganei, Tokyo 184-8588, Japan. Fax: +81 423887 044; Tel:

+81 423887 044; E-mail: hrc@cc.tuat.ac.jp

${ }^{b}$ Japan Science and Technology Agency (JST), ACT-C, 4-1-8 Honcho, Kawaguchi, Saitama, 332-0012, Japan.

${ }^{c}$ Department of Organic and Polymeric Materials, Graduate School of Science and Engineering, Tokyo Institute of Technology, Ookayama 2-12-1, Meguro-ku, Tokyo 152-8552, Japan. Fax: +81 357 342 888; Tel: +81 357343 757; E-mail: skawauch@polymer.titech.ac.jp

$\$$ Present address: Gakushuin University 


\begin{abstract}
:
The mechanistic studies for linear cross-dimerization between 2,3-dimethylbuta-1,3-diene and styrene by a $\operatorname{Ru}(0)$ complex, $\operatorname{Ru}\left(\eta^{6}\right.$-naphthalene $)\left(\eta^{4}-1,5-\mathrm{COD}\right)(\mathbf{1})$, are performed both by kinetic and computational studies. This reaction is basically zero-order to both of the diene and styrene concentrations and first-order to the catalyst concentration. The Hammett plot using $p$-substituted styrenes gives a linear relationship with a positive slope $(\rho=+0.482)$. The deuterium isotope experiment clearly shows the present reaction being a formal 1,4-addition of a $\mathrm{C}-\mathrm{H}$ bond in styrene to cisoid-1,3-diene. These kinetic studies show the reaction proceeding via oxidative coupling mechanism that is also supported by the DFT calculations.
\end{abstract}

\title{
Keywords:
}

Cross-dimerization, ruthenium(0), mechanism, oxidative coupling

\section{Introduction}

Direct carbon-carbon bond formation by use of simple commodity chemicals has garnered much attention as a straightforward transformation process to give complex and valuable molecules with high atom and step economy [1]. The cross-dimerizations between conjugated dienes and alkenes have been documented by using the Ziegler-type catalyst systems, and combinations of transition-metal salt with alkylaluminum [2]. Similar catalytic 1,4-addition reactions of styrene to conjugated diene are recently documented by in situ reductions of $\mathrm{Fe}(\mathrm{II})$ [3] and $\mathrm{Co}$ (II) [4] with $\mathrm{Mg}$ and $\mathrm{Zn}$ metals, respectively. Although the cross-dimerization catalyzed by the $\mathrm{Fe}(\mathrm{II}) / \mathrm{Mg}$ system is proposed to proceed by an oxidative coupling mechanism, this pioneering work does not report the conclusive mechanistic evidence. The other potential mechanisms for a cross-dimerization are hydride-insertion mechanism [5] and C-H bond activation mechanism [6].

We have documented a series of homo- and cross-dimerization reactions between conjugated compounds and/or substituted alkenes by a $\mathrm{Ru}(0)$ catalyst. A considerable mechanistic breakthrough was isolation of a ruthenacyclopentane, trans- $\left[\mathrm{Ru}\left[\mathrm{C}^{1} \mathrm{H}\left(\mathrm{CO}_{2} \mathrm{Me}\right) \mathrm{C}_{2} \mathrm{H}_{4} \mathrm{C}^{4} \mathrm{H}\left(\mathrm{CO}_{2} \mathrm{Me}\right)-\kappa^{2}-C^{1}, C^{4}\right]\left(\eta^{4}-1,5-\mathrm{COD}\right)(\mathrm{NCMe})_{2}\right]$ out of the reaction of $\left[\operatorname{Ru}\left(\eta^{6}\right.\right.$-naphthalene $\left.)\left(\eta^{4}-1,5-\mathrm{COD}\right)\right]$ (1) with methyl acrylate (Scheme 1), and the isolated ruthenacyclopentane also catalyzed tail-to-tail dimerization of methyl acrylate [7]. 


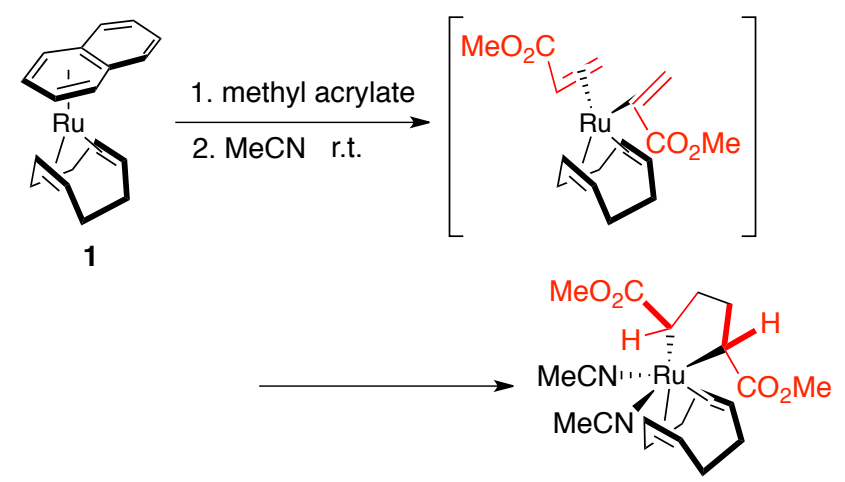

Scheme 1. Isolation of trans-2,5-bis(methoxycarbonyl)ruthenacyclopentane.

These findings were the first solid evidence in support of an oxidative coupling mechanism for tail-to-tail dimerization between substituted alkenes. On another front, we have also documented catalytic cross-dimerization between conjugated dienes and substituted alkenes [8]. However, we do not have adequate mechanistic evidence for the cross-dimerization. Although we have observed the formation of an $\eta^{1}: \eta^{3}$ ruthenacycle by the treatment of [Ru( $\eta^{4}$-buta-1,3-diene)( $\eta^{4}$-1,5-COD)(NCMe)] with vinyl acetate [Eq. (1)], this compound does not show the catalytic activity and therefore we cannot exclude the possibility of this compound being a dead-end species.

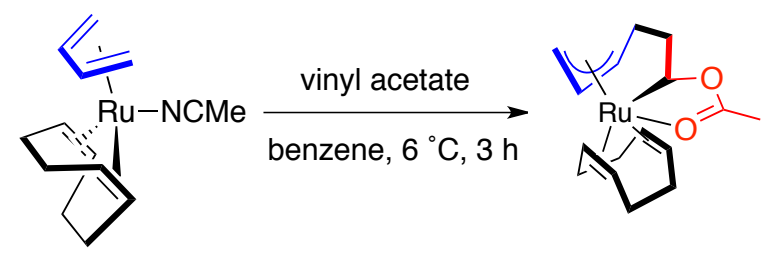

In this paper, we now disclose a solid evidence to support an oxidative coupling mechanism by the kinetic studies and DFT calculations for a catalytic cross-dimerization between conjugated diene and substituted alkenes.

\section{Results and discussion}

\subsection{Cross-dimerization between diene and styrenes}

The naphthalene complex 1 (2 mol\%) catalyzed the cross-dimerization between 2,3-dimethylbuta-1,3-diene (2) and styrene (3a) in toluene at $60{ }^{\circ} \mathrm{C}$ for $2 \mathrm{~h}$ to give the coupling 
products 4a (71\%) and 5a (9\%) along with 6 minor isomers (12\% in total) [Eq. (2)]. No homo-dimers were observed in this reaction. The upmost minor product is $\mathbf{5 a}$, a regioisomer of the $\mathrm{C}=\mathrm{C}$ bond of the major product $\mathbf{4 a}$. Notably, the relative $\mathbf{4 a} / \mathbf{5 a}$ ratio diminished with increase of the catalyst concentration (Table 1).

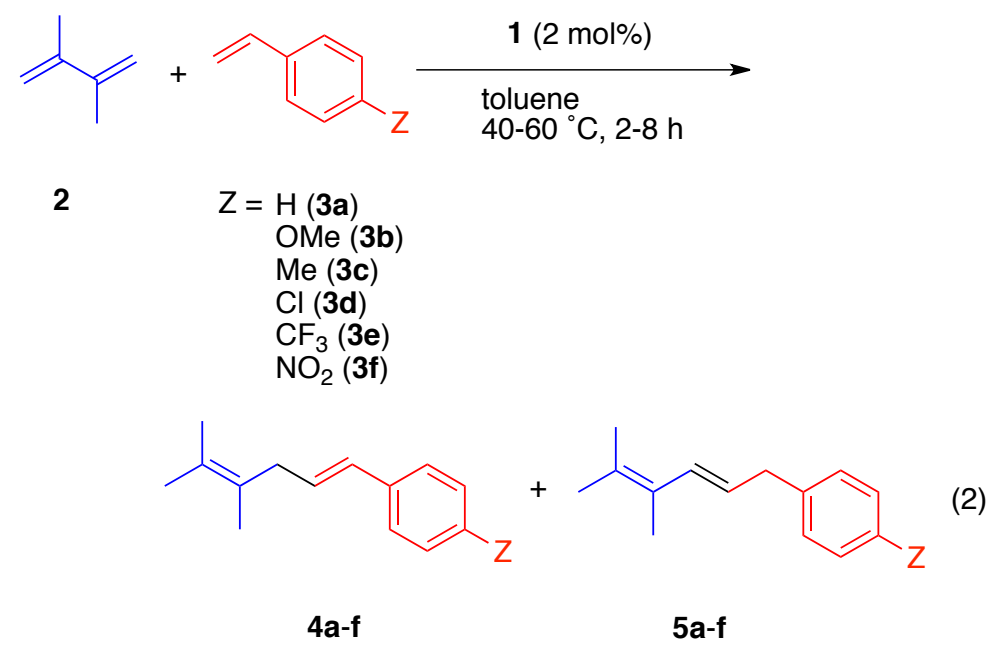

Table 1. The relation between catalyst concentration and major/minor ratio.

\begin{tabular}{l|lll} 
entry & $\mathbf{1 a} / \mathrm{mol} \%$ & total yield/\% & $\mathbf{4 a} / \mathbf{5 a}$ \\
1 & 0.5 & 39 & $6 / 1$ \\
2 & 1.0 & 52 & $6 / 1$ \\
3 & 2.0 & 74 & $6 / 1$ \\
4 & 4.0 & 74 & $4.5 / 1$ \\
5 & 10 & 65 & $2.6 / 1$ \\
6 & 20 & 61 & $1.3 / 1$
\end{tabular}

Conditions: $[\mathbf{2}] /[\mathbf{3 a}]=1.3 / 1,40{ }^{\circ} \mathrm{C}$, in toluene, $8 \mathrm{~h}$.

The isolated 4a did not cause spontaneous conversion into $5 \mathbf{a}$ at $40{ }^{\circ} \mathrm{C}$ in benzene- $d_{6}$ but the treatment of $4 \mathbf{a}$ with a catalytic amount of $1(10 \mathrm{~mol} \%)$ under the same conditions gave a mixture of 4a and 5a. The final 4a/5a ratio was $1 / 2$ under these conditions after $148 \mathrm{~h}$. These facts suggest the primary kinetic product $\mathbf{4 a}$ being converted into the thermodynamic product $\mathbf{5 a}$ by a Ru catalyst, and an equilibrium exists between them [Eq. (3)].

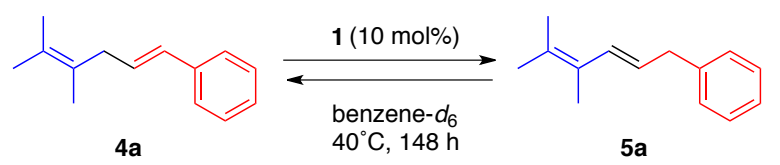




\subsection{Kinetic studies}

The time-course curves for the reaction of 2,3-dimethylbuta-1,3-diene with styrene by $\mathbf{1}$ were monitored by GLC, and the total sum yield of the cross-dimers, $\mathbf{4 a}$ and $\mathbf{5 a}$, showed a linear increase with time, suggesting a zero-order reaction. Fig. 1 shows the double logarithm plots for the relation of the formation rate of the products $\left(v_{\mathrm{p}}\right)$ with the diene (Fig. 1A), styrene (Fig. 1B) and catalyst concentrations (Fig. 1C). Although a slight dependence of the rate on the diene and styrene concentrations was observed in this range, this reaction is roughly regarded as a zero-order reaction to both of the concentrations [9]. The double logarithmic plot for the catalyst concentration and the rate at $40{ }^{\circ} \mathrm{C}$ shows a good linear relationship with a positive slope of +0.878 , which is consistent with the first-order to the catalyst concentration. Therefore, the present reaction can be summarized as the zero-order to both of diene and styrene concentrations and first-order to the catalyst concentration. 

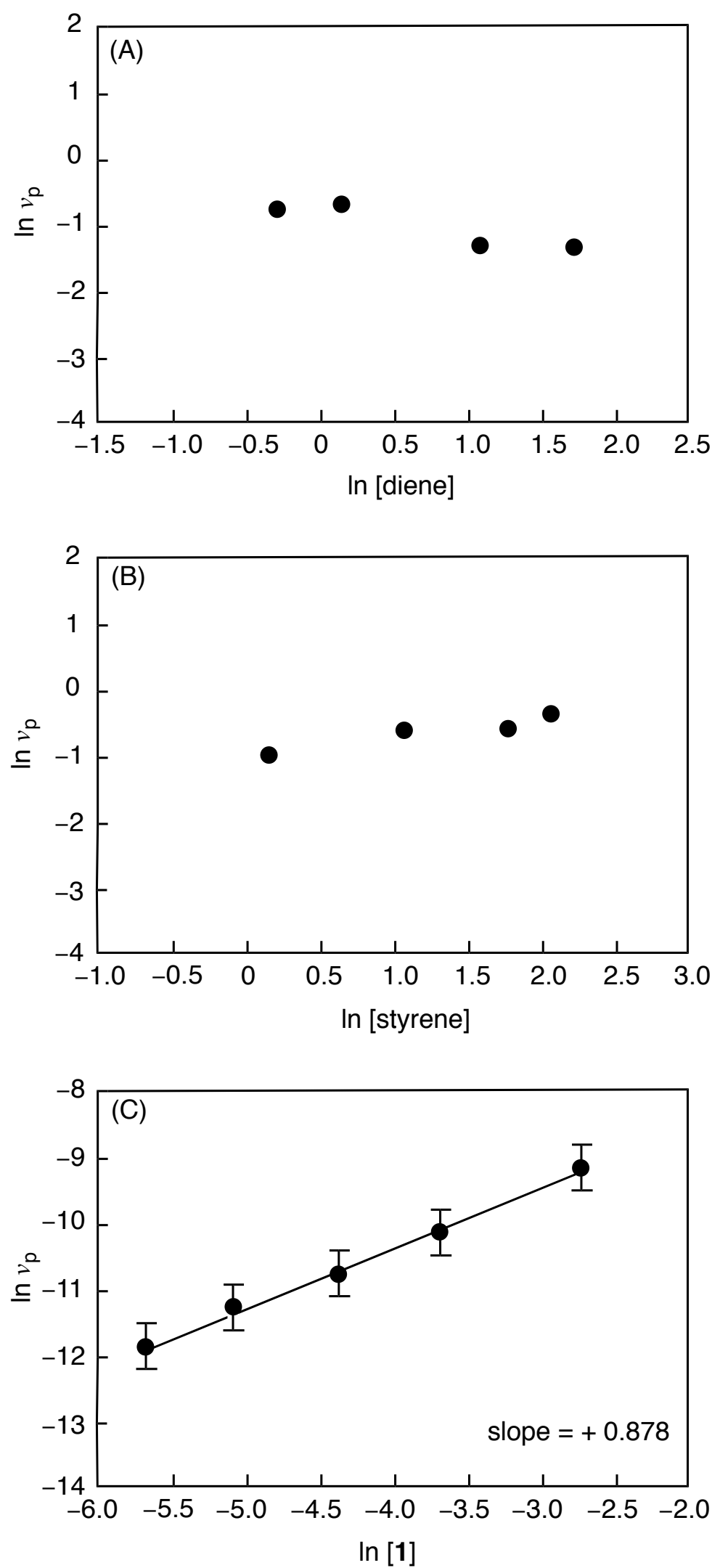

Fig. 1. Double-logarithm plots for the cross-dimerization between 2,3-dimethylbuta-1,3-diene and styrene. (A) Effect of concentration of diene on the rate. (B) Effect of concentration of styrene on the rate. Conditions: $[$ diene $]=0.59-5.58 \mathrm{M},[$ styrene $]=1.18-7.78 \mathrm{M} . \quad[1]=0.011 \mathrm{M}$, temp $=50{ }^{\circ} \mathrm{C}$, solvent $=$ toluene. $\quad(\mathrm{C})$ Effect of concentration of 1 on the rate. Conditions: $[1]=0.003-0.12 \mathrm{M}$, $[2,3$-dimethylbuta-1,3-diene $]=0.75 \mathrm{M}$, [ styrene $]=0.62 \mathrm{M}$, temp $=40{ }^{\circ} \mathrm{C}$, solvent $=$ toluene. 
Fig. 2 shows Hammett plot for cross-dimerization between 2,3-dimethylbuta-1,3-diene and a series of $p$-substituted styrenes 3a-f in toluene, showing the linear dependence with a positive slope $(\rho=+0.482)$ (Fig. 2).

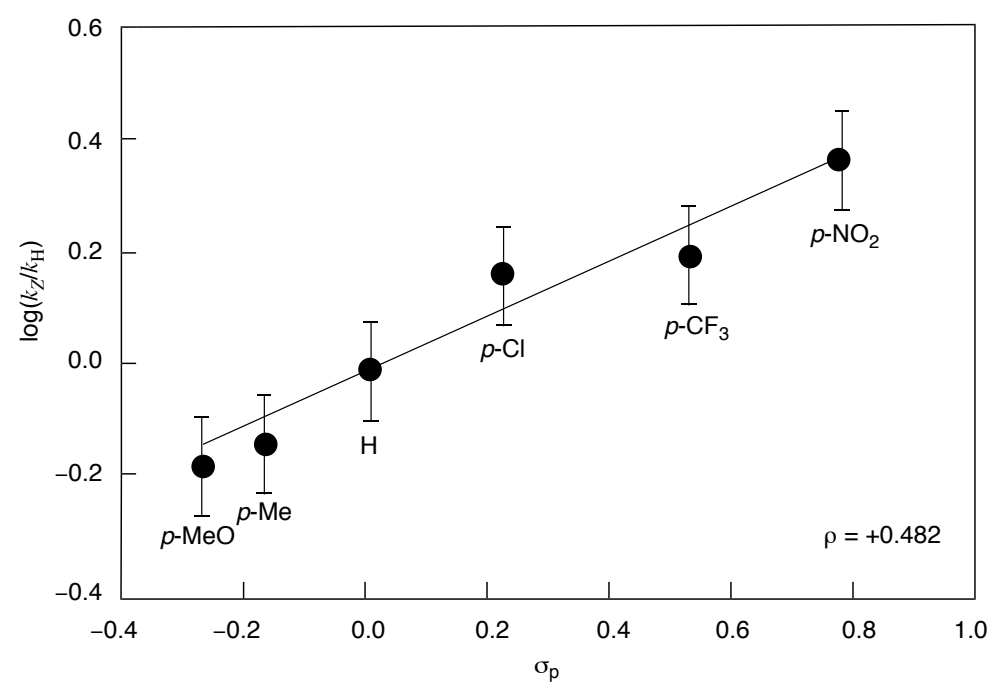

Fig. 2. Hammett plot for cross-dimerization between 2,3-dimethylbuta-1,3-diene and $p$-substituted styrenes. Conditions: $[\mathbf{1}]=0.01 \mathrm{M},[2,3$-dimethylbuta-1,3-diene $]=0.71 \mathrm{M},[p$-substituted styrene $]=$ $0.61 \mathrm{M}$, temp $=40{ }^{\circ} \mathrm{C}$, solvent $=$ toluene.

Eyring plot for overall formation reaction of $\mathbf{4 a}$ and $\mathbf{5 a}$ by $\mathbf{1}$ ( $2 \mathrm{~mol} \%)$ was measured in toluene: $\Delta H^{\ddagger}=70.2 \mathrm{~kJ} \mathrm{~mol}^{-1}, \Delta G^{\ddagger}{ }_{298}=104 \mathrm{~kJ} \mathrm{~mol}^{-1}$, and $\Delta S^{\ddagger}=-115 \mathrm{~J} \mathrm{~K}^{-1} \mathrm{~mol}^{-1}$. The large negative entropy of activation suggests involvement of a distorted transition state.

In order to confirm whereabouts of the cleaved hydrogen, we have employed styrene- $\beta, \beta$ ' $-d_{2}$ (95 atom \% D) for this cross-dimerization. In the cross-dimer, the deuterium atoms were distributed among the (Z)-1-, 4-, and 5-positions, and the deuterium atoms were not found in the other positions in the product $4 \mathbf{a}$ (Table 2$)$. 
Table 2. Distribution of deuterium atoms in the major product $4 \mathbf{a}^{\mathrm{a}}{ }^{\mathrm{a}}$

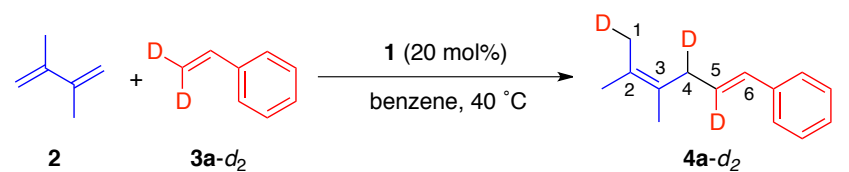

$\begin{array}{llll}\text { time } / \min & \mathrm{C}(1) \text { atom \% D } & \mathrm{C}(4) \text { atom \% D } & \mathrm{C}(5) \\ 5 & 88 & 21 & 83 \\ 70 & 89 & 35 & 68\end{array}$

${ }^{\mathrm{a}}$ The deuterium content was calculated based on the one proton at each carbon.

Based on the time-course of the reaction monitored by NMR, the deuterium atoms exclusively located among the (Z)-1- and 5-positions at the initial stage, and then a H/D exchange reaction occurs between the 4- and 5-positions while the deuterium content at the (Z)-1-position remains intact throughout the reaction. The total sum of deuterium atoms in $\mathbf{4 a}$ roughly indicates two $\mathrm{D}$ atoms being incorporated in 4a regardless of the reaction time, suggesting the following H/D exchange reaction between the 4and 5-positions to be an intramolecular process in $\mathbf{4 a -} d_{2}$. Note that only the methyl group [(Z)-C(1)], cis to the styryl fragment, was deuterated and no incorporation of the $\mathrm{D}$ atom was observed in the trans-methyl $\left[(E)-C\left(1^{\prime}\right)\right]$ position (Scheme 2$)$. These facts suggest the present initial reaction being regarded as a 1,4-addition of trans- $\beta-\mathrm{C}-\mathrm{D}$ bond in styrene to cisoid-2,3-dimethylbuta-1,3-diene, and then a site-selective H/D exchange reaction between 4- and 5-positions occurs by an intramolecular process.
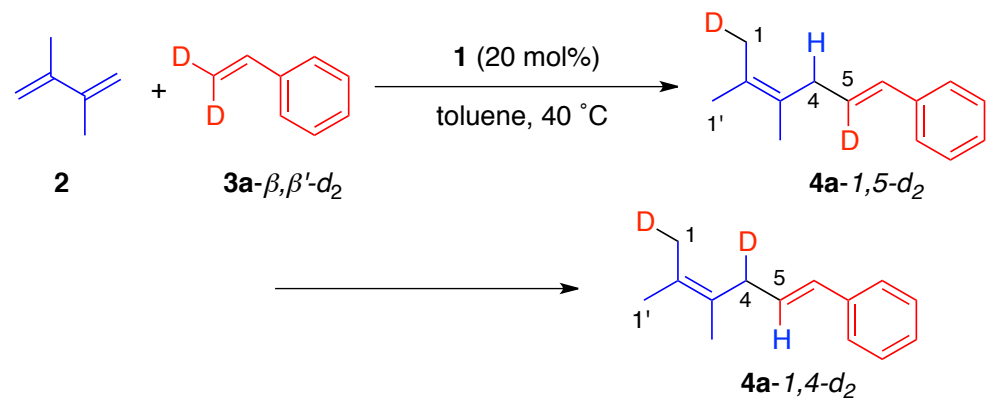

Scheme 2. Site-selective distribution of deuterium atoms in $\mathbf{4 a}-d_{2}$.

For the minor conjugated product 5a, the deuterium atoms also found at the $(Z)-1,4-, 5$ - and 6-positions (Chart 1). The total sum of D atoms was around two, suggesting an intramolecular deuterium distribution process in the cross-dimer- $d_{2}$. 
Chart 1. Deuterium distribution in $\mathbf{5 a}-d_{2}$.

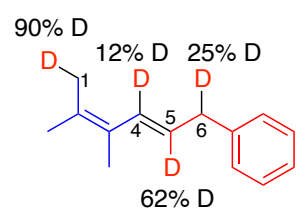

It is noteworthy that the one deuterium atom has mainly moved to the $(Z)-\mathrm{C}(1)$ position $(90 \%$ atom $\mathrm{D}$ ) and the other deuterium atom was distributed among $\mathrm{C}(4), \mathrm{C}(5)$ and $\mathrm{C}(6)$ positions.

Although this process involves complicated isomerization processes for the deuterium distribution in $\mathbf{4 a}$ and $\mathbf{5 a}$ as shown above, the KIE values $\left(k_{\mathrm{H}} / k_{\mathrm{D}}\right)$ for the present cross-dimerization were measured using the initial rate. The KIE measured from the independent reactions was 0.99(4), but a very small KIE [1.30(3)] was observed by the competitive reaction in a same vessel. This fact may be consistent with the $\mathrm{C}-\mathrm{H}$ bond cleavage step being an irreversible process after a rate-determining step in a multi-step process [10]. Note that the KIE for the $\beta$-hydride elimination was reported to be around 2-3 for the syn elimination, and around 5-7 for the anti elimination, and the KIE for reductive elimination was reported to be 1.3-3 [11].

\subsection{Stoichiometric reactions in relation to the mechanism}

In order to understand the mechanism, we performed the stoichiometric reactions. Because the NMR experiments for the stoichiometric reaction using 2,3-dimethylbuta-1,3-diene and styrene gave a complex mixture, we described the mimic reaction of $\left[\mathrm{Ru}\left(\eta^{4}\right.\right.$-buta-1,3-diene $\left.)\left(\eta^{4}-1,5-\mathrm{COD}\right)(\mathrm{NCMe})\right]$ (6) with methyl acrylate at first. Complex 6 reacted with methyl acrylate and the reaction at room temperature gave broad resonances in the ${ }^{1} \mathrm{H}$ NMR spectrum. On cooling to $-60{ }^{\circ} \mathrm{C}$, those resonances sharpened and the signals assignable to the coordinated and free methyl acrylate appeared separately. We have tentatively assigned this species as $\left[\mathrm{Ru}\left(\eta^{4}\right.\right.$-buta-1,3-diene $)\left(\eta^{2}\right.$-methyl acrylate $\left.)\left(\eta^{4}-1,5-C O D\right)\right]$ (7) by ${ }^{1} \mathrm{H}$ NMR and ${ }^{1} \mathrm{H}-{ }^{1} \mathrm{H}$ COSY (Scheme 3 ). 


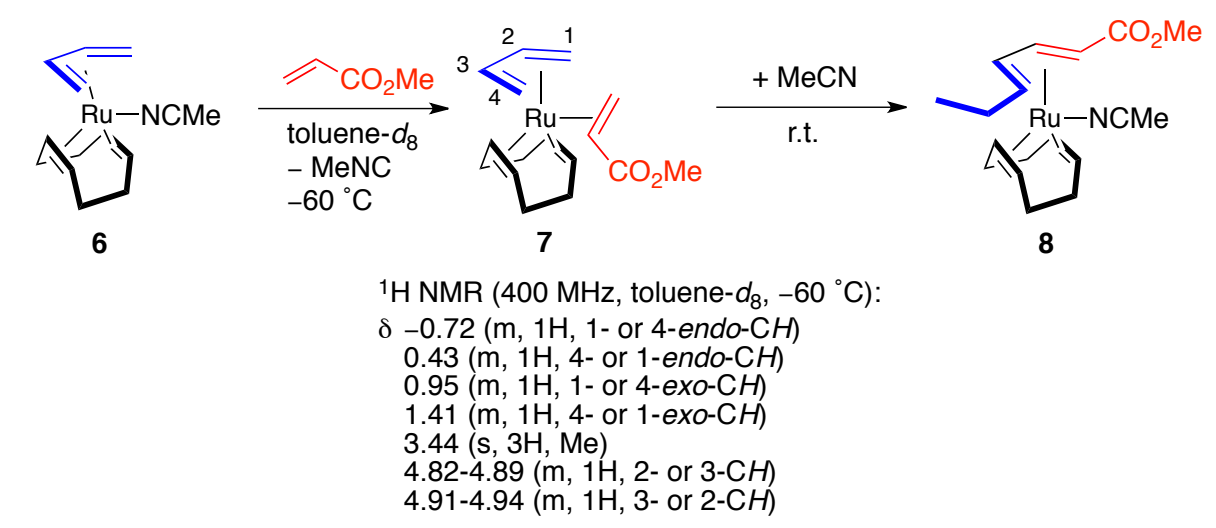

Scheme 3. Reaction of $\left[\mathrm{Ru}\left(\eta^{4}-\right.\right.$ buta-1,3-diene $\left.)\left(\eta^{4}-1,5-\mathrm{COD}\right)(\mathrm{NCMe})\right](6)$ with methyl acrylate.

The most characteristic feature of 7 in ${ }^{1} \mathrm{H}$ NMR spectrum in toluene- $d_{6}$ at $-60{ }^{\circ} \mathrm{C}$ is a $3 \mathrm{H}$ singlet at $\delta 3.44$ assignable to the methyl group of the coordinated methyl acrylate. Consistently, the buta-1,3-diene group was observed unsymmetrically and all resonances appeared separately, suggesting the coordination of a prostereogenic mono-substituted alkene. The alkenyl protons of acrylate obscured probably overlapped with the 1,5-COD protons. Complex 7 gradually converted into $\left[\mathrm{Ru}\left(\eta^{4}\right.\right.$-methyl hepta-2,4-dienoate) $\left.\left(\eta^{4}-1,5-\mathrm{COD}\right)(\mathrm{NCMe})\right]$ (8) [8] upon warming to room temperature. The observation of 7 affords collateral evidence for the formation of $\left[\mathrm{Ru}\left(\eta^{4}\right.\right.$-diene $)\left(\eta^{2}\right.$-alkene $\left.)\left(\eta^{4}-1,5-\mathrm{COD}\right)\right]$. Note that we have also documented observation of a similar intermediate $\left[\mathrm{Ru}\left(\eta^{4}\right.\right.$-cisoid-buta-1,3-diene $)\left(\eta^{2}\right.$-transoid-buta-1,3-diene $\left.)\left(\eta^{4}-1,5-\mathrm{COD}\right)\right]$ at -60 ${ }^{\circ} \mathrm{C}$ by ${ }^{1} \mathrm{H}$ NMR, where the $\eta^{2}$-transoid-buta-1,3-diene is labile and undergoes rapid exchange with free buta-1,3-diene while the $\eta^{4}$-cisoid-buta-1,3-diene binds tightly to the Ru center [12].

Because stoichiometric reaction of $\mathbf{6}$ with styrene gave a complex mixture, we tried the stoichiometric reaction of the naphthalene complex 1 with substrates. This experiment also gave less clear results than $\mathbf{7}$ because of following reasons: (i) only a portion of $\mathbf{1}$ reacted with substrates at low temperature, (ii) concomitant formation of at least two new species were observed even at low temperature, and (iii) dynamic behaviors of these new species and added styrene resonances were observed. However, growth of the broad resonances assignable to one of the new species was observed upon warming the mixture to $+10{ }^{\circ} \mathrm{C}$. In order to freeze the dynamic behavior, we measured it at $-80{ }^{\circ} \mathrm{C}$, and the broad resonances relatively sharpened. We tentatively assigned this species as $\left[\mathrm{Ru}\left(\eta^{4}-4,5\right.\right.$-dimethyl-1,4-hexadienylbenzene) $\left.\left(\eta^{4}-1,5-\mathrm{COD}\right)\right]$ (D) (Scheme 4). The ${ }^{1} \mathrm{H}$ NMR spectrum of this species contains three methyl peaks at $\delta 0.83(\mathrm{~s}, 3 \mathrm{H}), 1.32(\mathrm{~s}, 3 \mathrm{H})$ and $1.67(\mathrm{~s}$, $3 \mathrm{H}$ ), the diastereotopic methylene protons at $\delta 2.46$ (br.d, $J=4 \mathrm{~Hz}, 1 \mathrm{H})$ and $2.58(\mathrm{~s}, 1 \mathrm{H})$, and two coordinated alkenyl protons at $\delta 4.61$ (br.dd, $J=9,4 \mathrm{~Hz}, 1 \mathrm{H}$ ) and 4.70 (br.d, $J=9 \mathrm{~Hz}, 1 \mathrm{H}$ ). These resonances are consistent with the coordinated 4,5-dimethyl-1,4-hexadienylbenzene moiety in D [13]. 


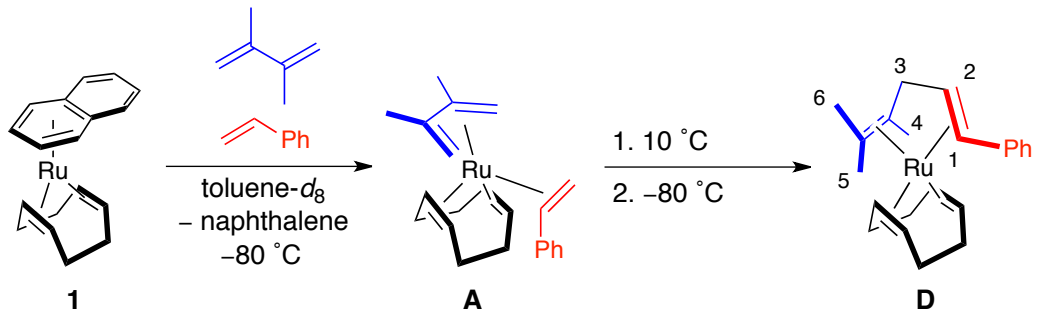

$$
\begin{aligned}
& { }^{1} \mathrm{H} \text { NMR }\left(400 \mathrm{MHz} \text {, toluene- } d_{8},-80{ }^{\circ} \mathrm{C}\right) \text { : } \\
& \delta 0.83(\mathrm{~s}, 3 \mathrm{H}, 6-\mathrm{Me}) \\
& 1.32(\mathrm{~s}, 3 \mathrm{H}, 5-M e) \\
& 1.67(\mathrm{~s}, 3 \mathrm{H}, 4-\mathrm{Me}) \\
& \left.2.46 \text { (br.d, } \mathrm{J}=4 \mathrm{~Hz}, 1 \mathrm{H}, 3-\mathrm{CH}_{2}\right) \\
& \left.2.58 \text { (br.s, } 1 \mathrm{H}, 3-\mathrm{CH}_{2}\right) \\
& 4.61 \text { (br.dd, } J=9,4 \mathrm{~Hz}, 1 \mathrm{H}, 2-\mathrm{CH}=) \\
& 4.70 \text { (br.d, } \mathrm{J}=9 \mathrm{~Hz}, 1 \mathrm{H}, 1-\mathrm{CH}=)
\end{aligned}
$$

Scheme 4. Reaction of $\left[\mathrm{Ru}\left(\eta^{4}-\right.\right.$-naphthalene $\left.)\left(\eta^{4}-1,5-\mathrm{COD}\right)\right](\mathbf{1})$ with 2,3-dimethylbuta-1,3-diene and styrene.

The other transient new species remains obscure because of severe overlapping among complex broad resonances. However, it contains characteristic singlets at $\delta-1.05$ and $\delta 1.86$ around $1: 3$ ratio, respectively, at $-80{ }^{\circ} \mathrm{C}$. A possible explanation for these resonances is due to the endo-methylene and methyl protons in the coordinated 2,3-dimethylbuta-1,3-diene, as observed for butadiene complex 7. Thus we presumed formation of a diene complex $\left[\operatorname{Ru}\left(\eta^{4}-2,3-\right.\right.$ dimethylbuta-1,3-diene $)\left(\eta^{2}\right.$-styrene $\left.)\left(\eta^{4}-1,5-\mathrm{COD}\right)\right](\mathbf{A})[14]$.

\subsection{Possible catalytic cycle}

All these experimental data are consistent with the catalytic cycle shown in Scheme 5.

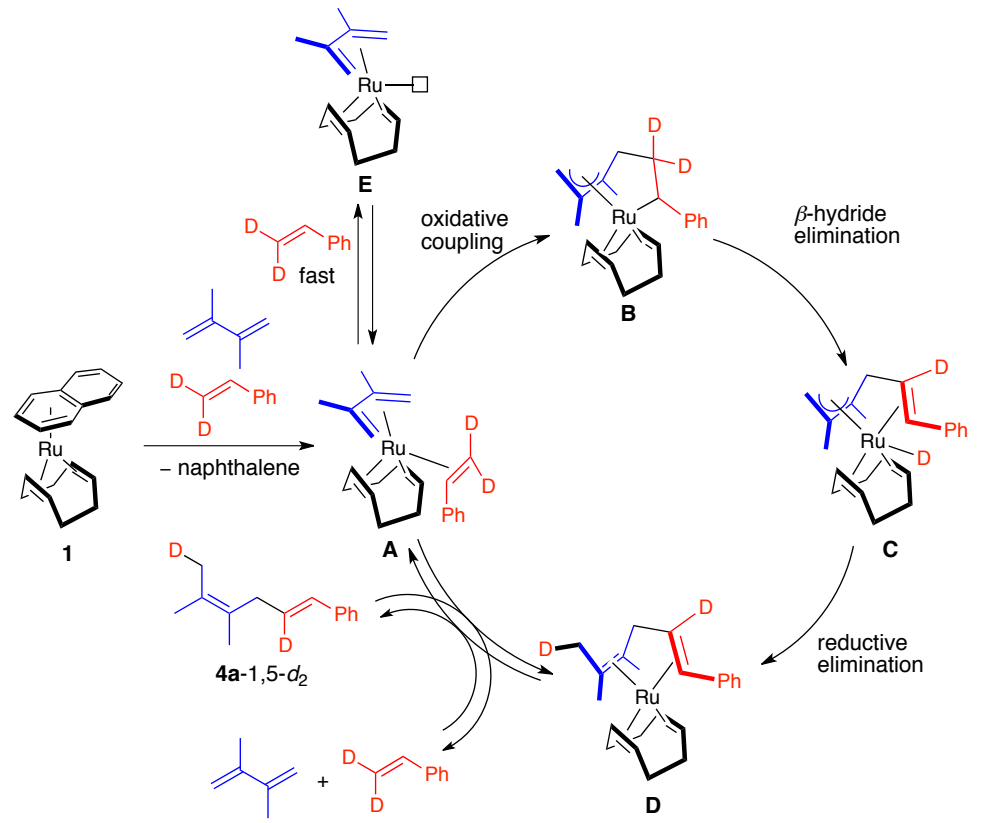

Scheme 5. Overall mechanism for the cross-dimerization of the product. 
In order to clarify the fate of the cleaved hydrogen, the reaction using styrene- $d_{2}$ is depicted in Scheme 5. Since the present reaction obeys zero-order kinetics to both of the diene and styrene concentrations, the presence of $\mathbf{A}$ is supported. The intermediate $\mathbf{A}$ is formed by displacement of the $6 \pi$ naphthalene ligand with 2,3-dimethylbuta-1,3-diene and styrene as $4 \pi$ and $2 \pi$ donors, respectively. This substrate selectivity is owing to the hapticity and is origin of the cross-dimerization. In fact we observed the related compound 7. Then an oxidative coupling reaction occurs at $\mathbf{A}$ to give a ruthenacycle $\mathbf{B}$. Note that we have obtained an analogue of $\mathbf{B}$ in the reaction of $\left[\mathrm{Ru}\left(\eta^{4}\right.\right.$-cisoid-buta-1,3-diene $\left.)\left(\eta^{4}-1,5-\mathrm{COD}\right)(\mathrm{NCMe})\right]$ with vinyl acetate [Eq. (1)] [8].

As shown in Fig 2, this cross-dimerization is promoted by electron deficient styrene. This fact can be explained by two reasons: $(i)$ facile coordination of the electron deficient styrene to the Lewis basic $\mathrm{Ru}(0)$ center, and/or (ii) lowering the energy of the LUMO in styrene fragment to enhance the oxidative coupling reaction. However, because present reaction is regarded as a zero-order to the styrene concentration, we believe the reason (ii) being responsible for this enhancement effect. Thus, the rate-determining step seems to involve the oxidative coupling step. The KIE values for this reaction are also consistent with this hypothesis. Subsequent $\beta$-hydride elimination gives $\mathbf{C}$ followed by the reductive elimination giving $\mathbf{D}$. The stoichiometric reaction also supports $\mathbf{D}$ as the final compound in the catalytic cycle. Finally, non-conjugated cross-dimer $\mathbf{4 a}-d_{2}$ is released. This mechanism well explains the formal 1,4-addition of styrene to diene as shown above. The $Z$ configuration of the $\mathrm{C}^{4}=\mathrm{C}^{5}$ bond in $\mathbf{4 a}-d_{2}$ is also consistent with this mechanism which extends back to the cisoid coordination of the diene in $\mathbf{A}$.

The site selective $\mathrm{H} / \mathrm{D}$ exchange process and isomerization of the $\mathrm{C}=\mathrm{C}$ bond are rather speculative but these processes are consistent with the pathways shown in Scheme 6 . The intermediate D having 4a-1,5- $d_{2}$ fragment causes a subsequent reaction involving an oxidative addition of the $\mathrm{C}-\mathrm{D}$ bond occurs to give $\mathbf{F}$, followed by $\beta$-hydride elimination to give an allene intermediate $\mathbf{G}$ or $\mathbf{H}$. Another possible pathway is formation of $\mathbf{C}$ from $\mathbf{D}$, followed by $\beta$-deuteride elimination to give $\mathbf{G}$ or $\mathbf{H}$. Note that we have documented coordination of cumulenes to the $\mathrm{Ru}\left(\eta^{4}-1,5-\mathrm{COD}\right)$ fragment $[15,16]$. Then the hydride and deuteride get back to the internal $\mathrm{C}=\mathrm{C}$ bond in allene to give either $4 \mathbf{a}-1,4-d_{2}$ or $\mathbf{5 a}-d_{2}$. 

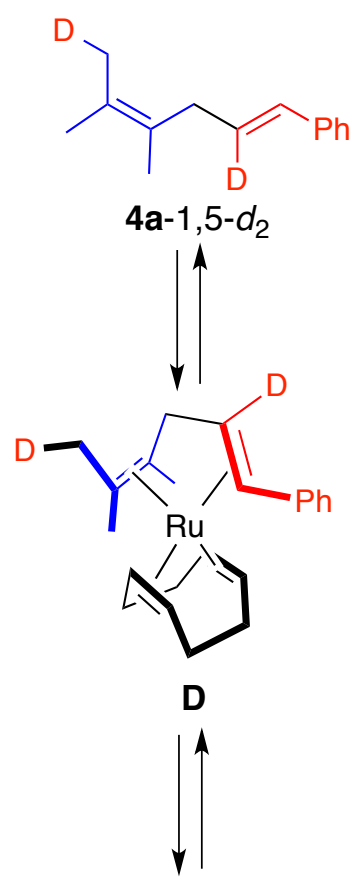

${ }_{\mathrm{R}_{\mathrm{Ru}}}^{\mathrm{Ph}}$

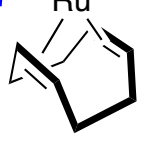

D'

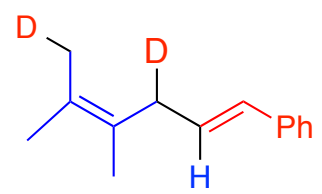

$4 a-1,4-d_{2}$
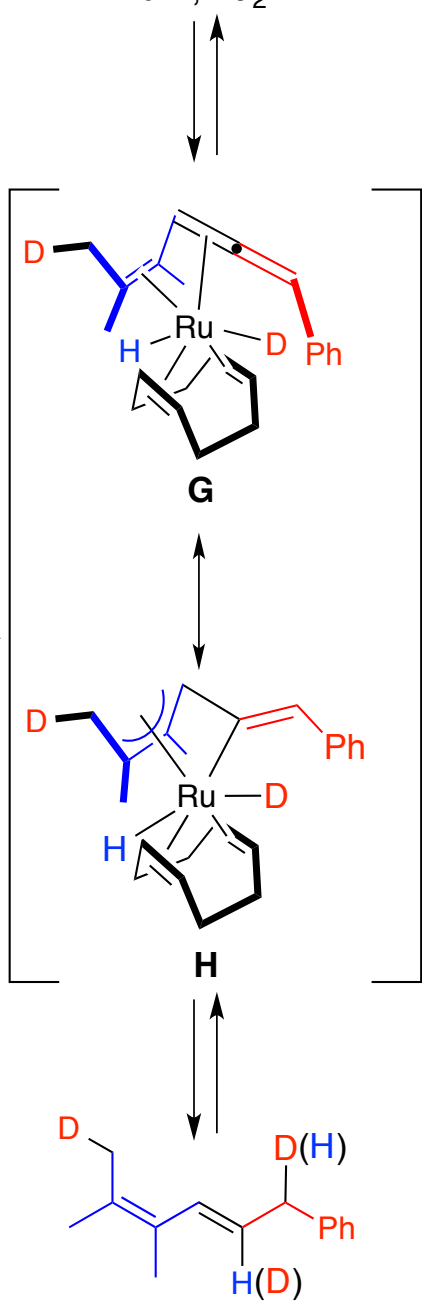

$5 \mathrm{a}-d_{2}$

Scheme 6. Possible mechanism for H/D exchange and isomerization of the product.

\subsection{DFT calculations}

In order to understand the detailed mechanism for the cross-dimerization, we have performed the DFT calculations. The calculated energy profile is illustrated in Fig. 3. It corresponds to the main catalytic cycle from initial complex $\mathbf{A}$ to final complex $\mathbf{D}$ as shown in Scheme 5, composed of oxidative coupling step, $\beta$-hydride elimination step, and reductive elimination step, respectively. The optimized geometries of the reactants, transition states, and products denoted in Fig. 3 are collected in the Fig. 4. As shown in Figs. 3 and 4, two intermediates, INT1 and INT2, are participated in the $\beta$-hydride elimination and reductive elimination steps, respectively. Interestingly, they are relatively 
stable complexes in which a hydride is attached to a carbon atom in the COD ligand. As a result, five transition states (TS1-TS5) were located in the cross-dimerization reaction. As shown in Fig. 4, the structures of TS2-TS5 resemble each other. However, they are clearly different each other because of distinct imaginary frequencies corresponding to each reaction coordinates and they are verified by the IRC calculations.

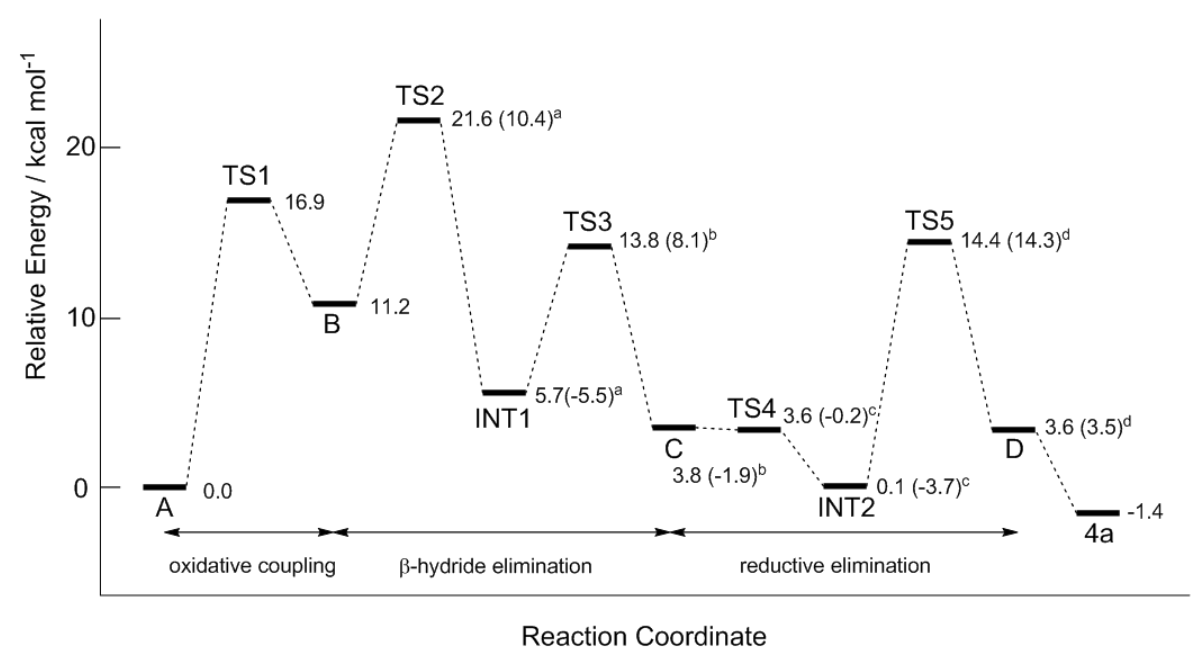

Fig. 3. Energy profile for the cross-dimerization reaction between 2,3-dimethylbut-1,3-diene and styrene. Energy values in parentheses are measured from a) B, b) INT1, c) C, and d) INT2, respectively. 


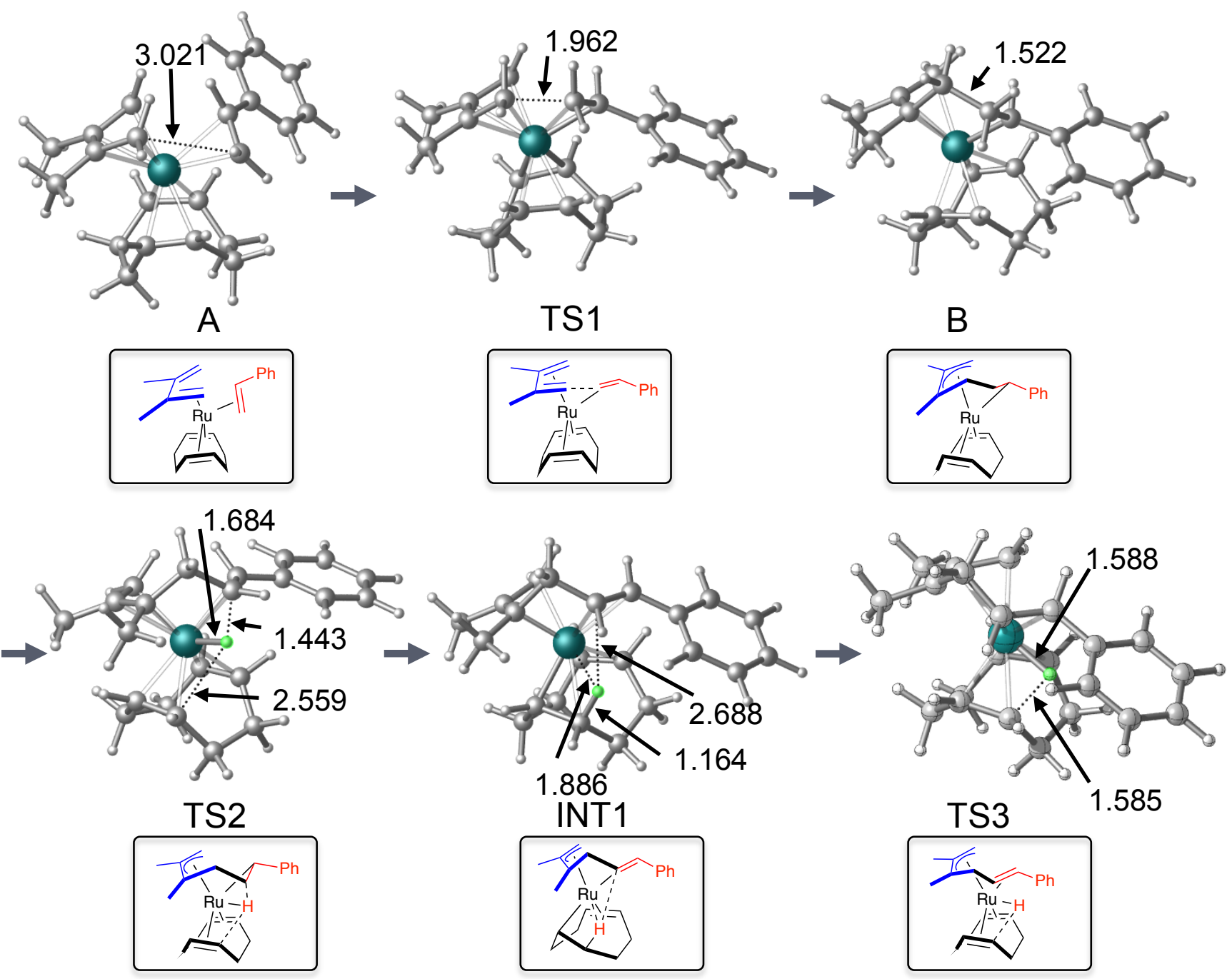




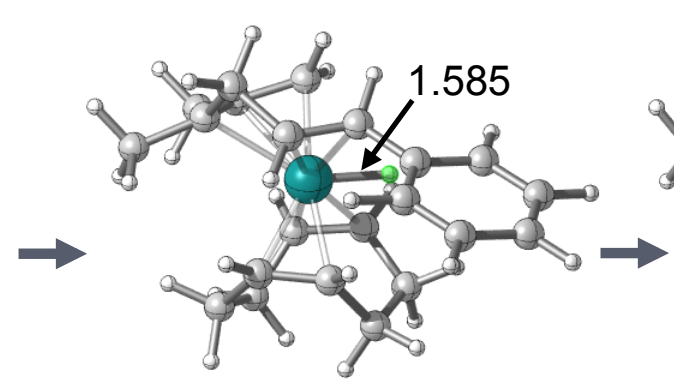

$\mathrm{C}$

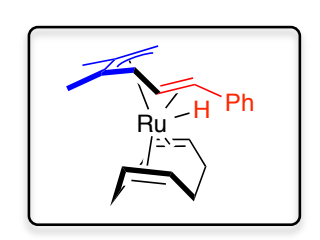

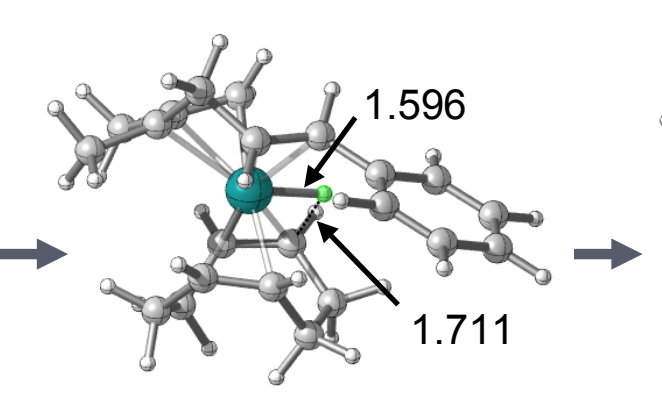

TS4

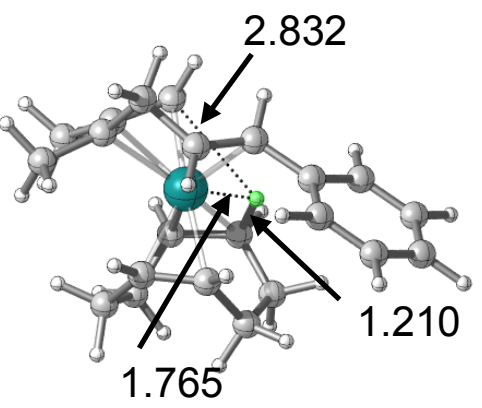

INT2
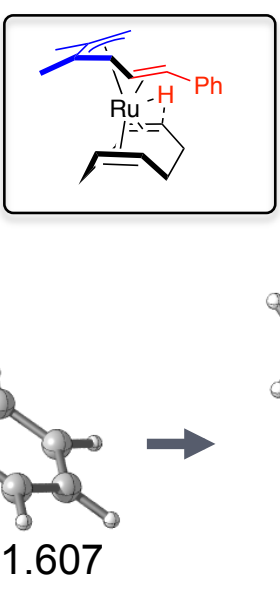

2.134

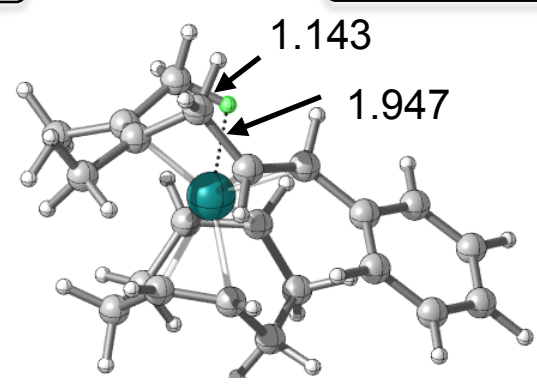

TS5

$\mathrm{D}$
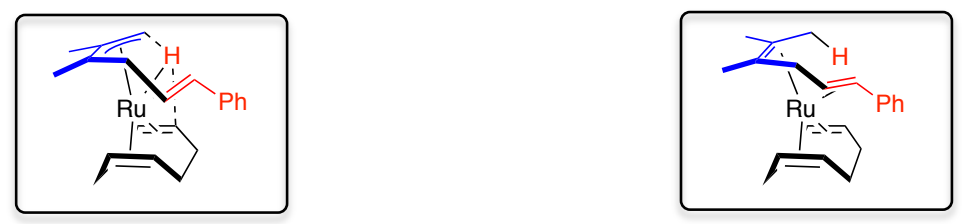

Fig. 4. Optimized structures for the cross-dimerization reaction between 2,3-dimethylbuta-1,3-diene and styrene as denoted in Fig. 3. Structures of intermediates and transition-states are also depicted below each ball-and-stick model. Selected bond lengths $(\AA)$ are shown in the figure. The transferring hydride is highlighted in green.

Many intermediates and transition states were obtained during investigation but the reaction paths directly connecting from $\mathbf{B}$ to $\mathbf{C}$, and from $\mathbf{C}$ to $\mathbf{D}$ without passing through the intermediates, INT1 and INT2, were failed to be located. In oxidative coupling step, the $\mathrm{C}-\mathrm{C}$ bond distance for coupling between diene and styrene changes from $3.021 \AA$ of $\mathbf{A}$ to $1.522 \AA$ of $\mathbf{B}$ via $1.962 \AA$ of $\mathbf{T S 1}$ as shown in Fig. 4. TS1 has an imaginary frequency of $204.4 i \mathrm{~cm}^{-1}$ corresponding to the reaction coordinate of $\mathrm{C}-\mathrm{C}$ coupling. The activation energy for oxidative coupling is $16.9 \mathrm{kcal} \mathrm{mol}^{-1}(70.8 \mathrm{~kJ}$ $\left.\mathrm{mol}^{-1}\right)$ and the heat of reaction is $11.2 \mathrm{kcal} \mathrm{mol}^{-1}\left(46.9 \mathrm{~kJ} \mathrm{~mol}^{-1}\right)$ endothermic as shown in Fig. 4.

Then, the $\beta$-hydride elimination step followed from $\mathbf{B}$ to $\mathbf{C}$ was examined carefully. The 
optimized geometries of transition states (TS2 and TS3), intermediate (INT1), and C are also shown in Fig. 4. The structure of TS2 is very close to that of $\mathbf{C}$, but the Ru-H bond (1.684 $\AA$ ) is quite elongated than that in $\mathbf{C}(1.585 \AA)$, and has an imaginary frequency of $596.8 \mathrm{i} \mathrm{cm}^{-1}$ corresponding to the hydride transfer from a carbon of styrene moiety to a carbon of the COD ligand. The following reaction proceeds from INT1 to $\mathbf{C}$ through TS3. The structure of TS3 is also close to that of $\mathbf{C}$ as shown in the figure, but TS3 has an imaginary frequency of $659.3 i \mathrm{~cm}^{-1}$ corresponding to hydride transfer from INT1 to C. The activation energy of TS2 is $10.4 \mathrm{kcal} \mathrm{mol}^{-1}\left(43.6 \mathrm{~kJ} \mathrm{~mol}^{-1}\right)$ measured from $\mathbf{B}$ and that of TS3 is $8.1 \mathrm{kcal} \mathrm{mol}^{-1}\left(34.8 \mathrm{~kJ} \mathrm{~mol}^{-1}\right)$ measured from INT1. The heats of reaction for INT1 and C are both exothermic. It is noteworthy that the hydride transfer from a carbon atom of the COD in INT1 to an adjoining carbon atom in the COD is difficult to occur because the reaction is $2.9 \mathrm{kcal} \mathrm{mol}^{-1}\left(12.2 \mathrm{~kJ} \mathrm{~mol}^{-1}\right)$ endothermic with relatively high activation energy of $35.5 \mathrm{kcal} \mathrm{mol}^{-1}$ $\left(148.7 \mathrm{~kJ} \mathrm{~mol}^{-1}\right.$ ) (these structures and energies are shown in Supporting Information). This is consistent with the experimental result in Table 2, where the contribution of hydride scrambling in deuterium distribution in the major product $\mathbf{4 a}$ is small.

The present calculations suggest the COD ligand being not a simple spectator ligand, and the $\mathrm{Ru}$ center mediates the hydride transfer from a methylene carbon in the ruthenacycle to the COD ligand. Such migration of a hydride in $\mathrm{Ru}-\mathrm{H}$ to $\eta^{4}-1,5-\mathrm{COD}$ ligand normally comes down an allylic $\eta^{3}-1-3-\mathrm{C}_{8} \mathrm{H}_{13}$ ligand [17]. However, a similar hydride migration giving $\eta^{1}-5: \eta^{2}-1,2-\mathrm{C}_{8} \mathrm{H}_{13}$ is reported in the reaction of $\left[\mathrm{RuH}\left(\eta^{4}-1,5-\mathrm{COD}\right)\left(\mathrm{NH}_{2} \mathrm{NMe}_{2}\right)_{3}\right] \mathrm{PF}_{6}$ with isocyanide to yield $\left[\mathrm{Ru}\left(\eta^{1}-5: \eta^{2}-1,2-\mathrm{C}_{8} \mathrm{H}_{13}\right)(\mathrm{CNR})_{4}\right] \mathrm{PF}_{6}[18]$.

The energy profile of reductive elimination step is also shown in Fig. 3. The intermediate (INT2) has lower energy of $3.7 \mathrm{kcal} \mathrm{mol}^{-1}\left(15.5 \mathrm{~kJ} \mathrm{~mol}^{-1}\right)$ than C. Transition state (TS4) can be located among them with barrierless. The transition state (TS5) followed by INT2 has activation energy of $14.3 \mathrm{kcal} \mathrm{mol}^{-1}\left(59.9 \mathrm{~kJ} \mathrm{~mol}^{-1}\right)$ and the final complex $\mathbf{D}$ has small endothermicity of $3.5 \mathrm{kcal}$ $\mathrm{mol}^{-1}\left(14.7 \mathrm{~kJ} \mathrm{~mol}^{-1}\right)$ relative to INT2.

These calculation results clearly show that the oxidative coupling step requires the largest activation barrier for TS1 throughout the reactions. To confirm this, the effect of substituents of styrene on activation energy of the oxidation coupling was investigated as shown in Fig. 5. The excellent linear relationship clearly indicates the electronic nature of styrene governs the rate of the overall reactions. 


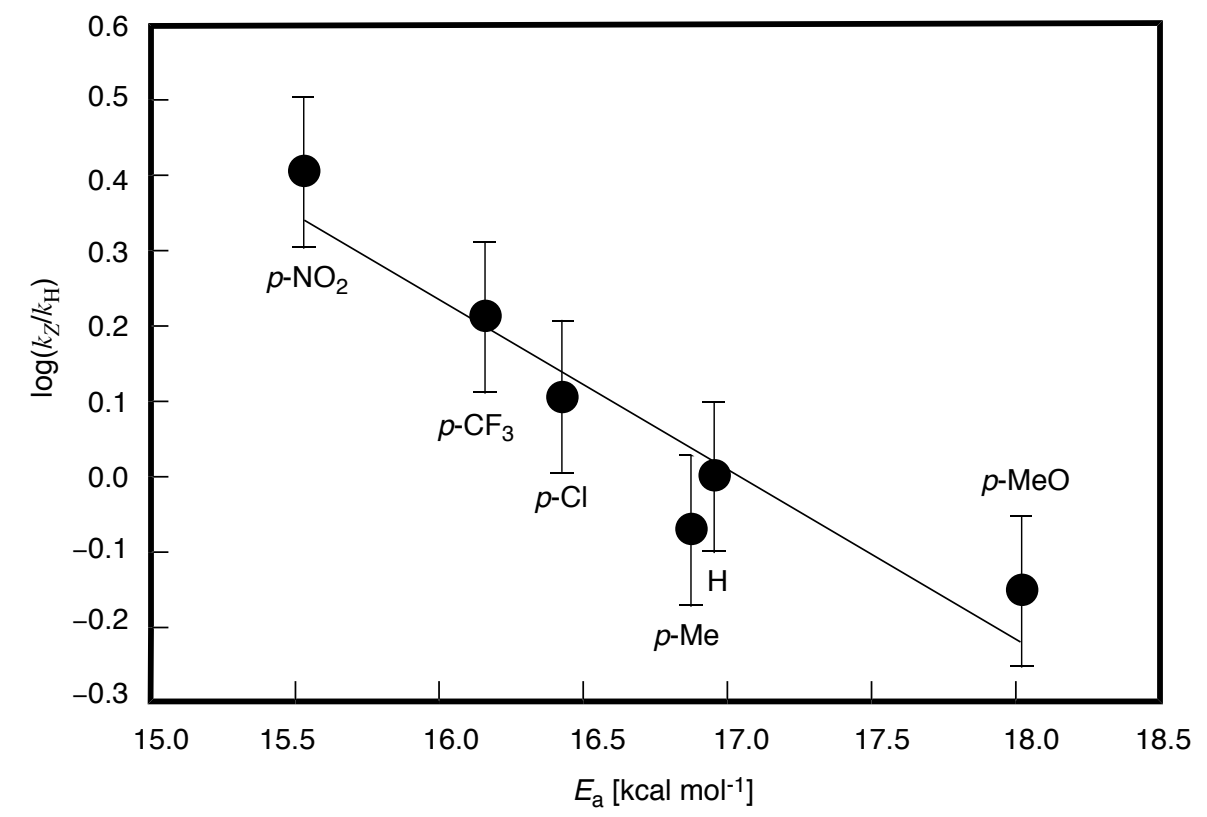

Fig. 5. Hammett-like plot against calculated activation energies for oxidative coupling reaction.

\subsection{Discussion}

The present studies strongly support an oxidative coupling mechanism for this reaction. These kinetic studies basically suggest the reaction to be a zero-order reaction to both of the diene and styrene concentrations. In other words, coordination of these substrates is not a rate-determining step. Therefore the Hammett plot with a positive $\rho$ value suggests electron-deficient styrene to promote the subsequent steps. In our system, $\beta$-hydride elimination would proceed from B (cf. Scheme 5), where an aryl group stands at the $\alpha$-position in a ruthenacycle. It is notable that Myers and coworkers have documented electron-withdrawing groups at the $\alpha$-position in an alkyl complex suppressing $\beta$-hydride elimination [19], but our system contradicts this feature. The isotopic labeling studies also show the $\mathrm{C}-\mathrm{H}$ bond cleavage step being an irreversible process after a rate-determining step. These kinetic results are consistent with the oxidative coupling step being rate-determining. In the energy profile by DFT calculations, the highest transition state in the energy diagram is TS2, which concerns the $\beta$ hydride elimination, but the transition state that requires the largest activation energy is TS1 in the oxidative coupling step (cf. Fig. 3). There is an argument of which step should be called as the rate-determining step. If the $\beta$-hydride elimination step is slow enough, the oxidative coupling step would constitute an equilibrium, that means the $\beta$-hydride elimination step being controlled by the concentration of $\mathbf{B}$. On the other hand, the $\beta$-hydride elimination step is quick enough, produced $\mathbf{B}$ would be consumed rapidly. In this case, the oxidative coupling step will govern the reaction. Unfortunately, we do not have information about reversibility of the oxidative coupling step, but this 
step is largest endothermic step in the present catalytic cycle. The energy difference means that this step largely leis on the $\mathbf{A}$ side $\left(K_{\mathrm{e}}=[\mathbf{B}] /[\mathbf{A}] \sim 10^{-9}\right.$ at $\left.298 \mathrm{~K}\right)$ even if this step were reversible. Therefore, the overall reaction would strongly depend on the oxidative coupling step and we can call this step being a practical rate-determining step. In fact, we obtained a good linear relationship between the logarithm of experimental relative rate constants and the calculated activation energies for the oxidative coupling reaction as shown in Fig. 5.

\section{Conclusion}

The present study supports an oxidative coupling mechanism for cross-dimerization between conjugated diene and alkene both by the kinetic and theoretical studies. The kinetic studies suggest prior coordination of both of diene and styrene to the $\mathrm{Ru}(0)$ center and the electron deficient styrene promotes the cross-dimerization. The computational studies are also consistent with the kinetic results and engage the oxidative coupling step to govern the overall reaction. This is the first solid evidence in support of oxidative mechanism for the cross-dimerizations between dienes and alkenes. The calculations also suggest that the COD ligand is actually not a simple spectator ligand but it engages to assist the hydrogen migration steps.

\section{Experimental}

\subsection{General procedures}

All manipulations and reactions were performed under dry nitrogen or argon with use of standard Schlenk and vacuum line techniques. Benzene, toluene, hexane, tetrahydrofuran (THF) and $\mathrm{Et}_{2} \mathrm{O}$ were purified by Glass Contour Ultimate Solvent Purification System. Benzene- $d_{6}$ and toluene- $d_{8}$ were dried over sodium wire, and these solvents were stored under vacuum. 2,3-Dimethylbuta-1,3-diene (99.0\% pure) was purchased from Aldrich and used as received. [Ru( $\eta^{6}$-naphthalene $\left.)\left(\eta^{4}-1,5-\mathrm{COD}\right)\right](\mathbf{1})$ was prepared according to the literature procedure [2]. All other reagents were obtained from commercial suppliers (Wako Pure Chemical Industry, Aldrich, or TCI) and used as received. NMR spectra were recorded on JEOL ECX400P $\left({ }^{1} \mathrm{H}\right.$ at $399.8 \mathrm{MHz},{ }^{13} \mathrm{C}$ at $100.5 \mathrm{MHz}$ ) spectrometer. Tetramethylsilane was used as reference for ${ }^{1} \mathrm{H}$ and ${ }^{13} \mathrm{C}$ spectra. The GLC analyses were performed on Shimadzu GC14B equipped with a TC-WAX (0.25 $\mathrm{mm} \phi \times 30 \mathrm{~m})$ under the following conditions: initial temp. $=50{ }^{\circ} \mathrm{C}$, initial time $=5 \mathrm{~min}$, program rate $=5{ }^{\circ} \mathrm{C} / \mathrm{min}$, final temp. $=220{ }^{\circ} \mathrm{C}$, injector temp. $=200{ }^{\circ} \mathrm{C}$, detector temp. $=200{ }^{\circ} \mathrm{C}$. GC-MS was measured on a 
Shimadzu QP2010 by use of the electron impact method.

\subsection{Reactions of 2,3-dimethylbuta-1,3-diene with styrene}

A toluene solution ( $2 \mathrm{ml}$ ) of 2,3-dimethylbuta-1,3-diene (2) (200 $\mu 1,1.77 \mathrm{mmol})$ and styrene (3a) $(170 \mu 1,1.48 \mathrm{mmol}$ ) was added into Ru(naphthalene)(COD) (1) $(10.3 \mathrm{mg}, 0.03 \mathrm{mmol}, 2 \mathrm{~mol} \%$ ) and the reaction mixture was stirred at $50{ }^{\circ} \mathrm{C}$ for $5 \mathrm{~h}$. The product yield and product ratio were determined by GC analysis using dibenzyl (49.9 $\mathrm{mg}, 0.27 \mathrm{mmol})$ as an initial standard. Yield $84 \%$ $(\mathbf{4 a} / \mathbf{5 a} /$ isomers $=79 / 13 / 8)$. These products were identified by NMR spectra after purification by silicagel chromatography with hexane as an eluent. (E)-(4,5-dimethyl-1,4-hexadienyl)benzene (4a). ${ }^{1} \mathrm{H}$ NMR (400 MHz, chloroform-d, r.t.): $\delta 7.35$ (d, $\left.J=8.0 \mathrm{~Hz}, 2 \mathrm{H},-P h\right), 7.26(\mathrm{t}, J=8.0 \mathrm{~Hz}, 2 \mathrm{H},-P h)$, $7.16(\mathrm{t}, J=7.4 \mathrm{~Hz}, 1 \mathrm{H},-P h), 6.33(\mathrm{~d}, J=16.0 \mathrm{~Hz}, 1 \mathrm{H},=\mathrm{CH}-), 6.14(\mathrm{dt}, J=16.0 \mathrm{~Hz}, 6.3 \mathrm{~Hz}, 1 \mathrm{H}$, $=\mathrm{CH}-), 2.90\left(\mathrm{~d}, \mathrm{~J}=6.3 \mathrm{~Hz}, 2 \mathrm{H},-\mathrm{CH}_{2^{-}}\right), 1.69$ (s, 3H, 1-Me cis to methylene), 1.67 (s, 3H, 3-Me), 1.65 (s, 3H, 2-Me): These assignments were confirmed by NOESY. ${ }^{1} \mathrm{H}$ NMR (400 MHz, benzene- $d_{6}$, r.t.): $\delta$ $7.25(\mathrm{~m}, 2 \mathrm{H},-P h), 7.12(\mathrm{~m}, 2 \mathrm{H},-P h), 7.03(\mathrm{~m}, 1 \mathrm{H},-P h), 6.36(\mathrm{~d}, J=15.5 \mathrm{~Hz}, 1 \mathrm{H},=\mathrm{CH}-), 6.11(\mathrm{dt}, J=$ $15.4 \mathrm{~Hz}, 6.8 \mathrm{~Hz}, 1 \mathrm{H},=\mathrm{CH}-), 2.84\left(\mathrm{~d}, J=6.3 \mathrm{~Hz}, 2 \mathrm{H},-\mathrm{CH}_{2^{-}}\right), 1.64(\mathrm{~s}, 6 \mathrm{H},-M e), 1.62$ (s, 3H, $\left.-\mathrm{Me}\right)$. ${ }^{13} \mathrm{C}\left\{{ }^{1} \mathrm{H}\right\}$ NMR (100 MHz, benzene-d 6 , r.t.): $\delta 141.0$ (s), 131.0 (s), 129.0 (s), 128.9 (s), 126.0 (s), 125.0
(s), $\quad 40.1$
(s), $\quad 21.6$
(s), $\quad 21.0$
$(\mathrm{s}), \quad 14.6 \quad(\mathrm{~s})$.
GC-MS:
$\mathrm{m} / \mathrm{z}=186\left(\mathrm{M}^{+}\right)$.

(E)-(4,5-dimethyl-2,4-hexadienyl)benzene (5a). ${ }^{1} \mathrm{H}$ NMR (400 MHz, benzene- $d_{6}$, r.t.): $\delta 7.16$ (m, 4H, $-P h), 7.05(\mathrm{~m}, 1 \mathrm{H},-P h), 6.66(\mathrm{~d}, J=14.8 \mathrm{~Hz}, 1 \mathrm{H},=\mathrm{CH}-), 5.71(\mathrm{dt}, J=15.4 \mathrm{~Hz}, 6.8 \mathrm{~Hz}, 1 \mathrm{H}, 2-\mathrm{CH})$, $3.36\left(\mathrm{~d}, J=6.9 \mathrm{~Hz}, 2 \mathrm{H},-\mathrm{CH}_{2}-\right), 1.70(\mathrm{~s}, 6 \mathrm{H},-\mathrm{Me}), 1.62(\mathrm{~s}, 3 \mathrm{H},-\mathrm{Me}) . \quad{ }^{13} \mathrm{C}\left\{{ }^{1} \mathrm{H}\right\} \mathrm{NMR}(100 \mathrm{MHz}$, benzene- $d_{6}$, r.t.): $\delta 138.26$ (s), 130.49 (s), 128.61 (s), 127.08 (s), 38.36 (s), 20.67 (s), 20.26 (s), 18.56 (s). GC-MS: m/z=186( $\left.\mathrm{M}^{+}\right)$.

\subsection{Synthesis of styrene- $\beta, \beta$ ' $-d_{2}$.}

In a $500 \mathrm{ml} \mathrm{Schlenk} \mathrm{tube,} \mathrm{PPh}_{3}(15.5466 \mathrm{~g}, 0.05927 \mathrm{~mol})$ was placed and THF $(90 \mathrm{ml})$ was added. $\mathrm{CD}_{3} \mathrm{I}(3.8 \mathrm{ml}, 0.05927 \mathrm{mmol})$ was added into the solution and the reaction mixture was refluxed for an hour. After cooling to room temperature, the resulting white solid was separated and was washed with $\mathrm{Et}_{2} \mathrm{O}\left(20 \mathrm{ml}\right.$, twice) and dried under reduced pressure to give $\left[\mathrm{PPh}_{3}\left(\mathrm{CD}_{3}\right)\right] \mathrm{I}(24.3235 \mathrm{~g}, 0.05927$ mol) in $100 \%$ yield (99\% atom D). $\quad\left[\mathrm{PPh}_{3}\left(\mathrm{CD}_{3}\right)\right] \mathrm{I}(24.3235 \mathrm{~g}, 0.0593 \mathrm{mmol})$ was suspended in $\mathrm{Et}_{2} \mathrm{O}$ $(80 \mathrm{ml})$ and tert-BuOK $(6.3078 \mathrm{~g}, 0.5621 \mathrm{~mol})$ was added into the reaction mixture, during which the white suspension turned to yellow suspension. After $2 \mathrm{~h}$, benzaldehyde $(5.8 \mathrm{ml}, 0.0568 \mathrm{~mol})$ was slowly dropped into the solution at $-65{ }^{\circ} \mathrm{C}$ to give a white suspension. The reaction mixture was stirred for a night and was allowed to rise to room temperature. Then, water $(30 \mathrm{ml})$ was added into 
the suspension and the product was extracted with $\mathrm{Et}_{2} \mathrm{O}$. The ether solution was washed with $\mathrm{NaHSO}_{3}$ aq $(10 \mathrm{ml})$, and brine $(10 \mathrm{ml})$, and then dried with $\mathrm{MgSO}_{4}$. The solution was concentrated under atmospheric pressure and the product was purified with silicagel chromatography using pentane as an eluent. The product was dried with $\mathrm{CaH}$ and was distilled under vacuum to give styrene- $\beta, \beta^{\prime}-d_{2}$ $\left(\mathbf{3 a}-d_{2}\right)$. Yield: $3.7317 \mathrm{~g}\left(\mathbf{3 a}-d_{2} /\right.$ pentane $=4.7 / 1$, net $\left.\mathbf{3 a}-d_{2}=0.0288 \mathrm{~mol}, 49 \%\right)$.

\subsection{Effect of substrate concentrations}

Similar to above reaction, the reactions were repeated with different substrate concentrations at 50 ${ }^{\circ} \mathrm{C}$ for $5 \mathrm{h:} 2(1660 \mu \mathrm{l}, 14.7 \mathrm{mmol}), 3 \mathrm{a}(170 \mu \mathrm{l}, 1.48 \mathrm{mmol}), \mathbf{1}(10.0 \mathrm{mg}, 0.03 \mathrm{mmol})$, toluene $(0.8 \mathrm{ml})$, yield 90\% (4a/5a/isomers $=87 / 9 / 4) . \quad 2(830 \mu 1,7.37 \mathrm{mmol}), \mathbf{3 a}(170 \mu 1,1.48 \mathrm{mmol}), \mathbf{1}(10.0 \mathrm{mg}$, $0.03 \mathrm{mmol})$, toluene $(1.6 \mathrm{ml})$, yield $86 \%(\mathbf{4 a} / \mathbf{5 a} /$ isomers $=82 / 12 / 6) . \quad 2(330 \mu 1,2.93 \mathrm{mmol}), \mathbf{3 a}(170$ $\mu 1,1.48 \mathrm{mmol}), \mathbf{1}(10.1 \mathrm{mg}, 0.03 \mathrm{mmol})$, toluene $(2 \mathrm{ml})$, yield $88 \%(\mathbf{4 a} / \mathbf{5 a} /$ isomers $=78 / 9 / 13) . \quad 2$ (166 $\mu \mathrm{l}, 1.48 \mathrm{mmol}), 3 \mathrm{a}(340 \mu \mathrm{l}, 2.96 \mathrm{mmol}), 1(9.8 \mathrm{mg}, 0.03 \mathrm{mmol})$ toluene $(2 \mathrm{ml})$, yield 64\% $(\mathbf{4 a} / \mathbf{5 a}$ /isomers $=34 / 59 / 6) . \quad \mathbf{2}(167 \mu 1,1.48 \mathrm{mmol}), \mathbf{3 a}(830 \mu 1,7.25 \mathrm{mmol})$ in toluene $(1.5 \mathrm{ml})$ were added into $\mathrm{Ru}($ naphthalene)(COD) $\mathbf{1}(10.0 \mathrm{mg}, 0.03 \mathrm{mmol})$, yield 65\% (4a/5a/isomers $=63 / 32 / 5) .2$ (167 $\mu \mathrm{l}, 1.48 \mathrm{mmol}), 3 \mathrm{a}(1690 \mu \mathrm{l}, 14.77 \mathrm{mmol}), 1$ (10.0 mg, $0.03 \mathrm{mmol})$, toluene $(0.6 \mathrm{ml})$ yield $58 \%$ $(\mathbf{4 a} / \mathbf{5 a} /$ isomers $=74 / 21 / 5)$.

\subsection{Effect of catalyst concentration}

$2(200 \mu \mathrm{l}, 1.77 \mathrm{mmol}), 3 \mathrm{a}(170 \mu \mathrm{l}, 1.48 \mathrm{mmol}), \mathbf{1}(10.0 \mathrm{mg}, 0.03 \mathrm{mmol})$, toluene $(2 \mathrm{ml}), 40{ }^{\circ} \mathrm{C} .9 \mathrm{~h}$. Yield: $62 \%(\mathbf{4 a} / \mathbf{5 a} /$ isomers $=77 / 15 / 8) . \quad 2(200 \mu 1,1.77 \mathrm{mmol}), \mathbf{3 a}(170 \mu 1,1.48 \mathrm{mmol}), 1$ (4.93 mg, $0.015 \mathrm{mmol})$, toluene $(2 \mathrm{ml}), 50{ }^{\circ} \mathrm{C}, 10 \mathrm{~h} . \quad$ Yield: $52 \%(\mathbf{4 a} / \mathbf{5 a} /$ isomers $=83 / 12 / 5) . \quad 2(200 \mu 1,1.77$ mmol), 3a (170 $\mu 1,1.48 \mathrm{mmol}), 1(19.7 \mathrm{mg}, 0.058 \mathrm{mmol})$, toluene $(2 \mathrm{ml}), 50{ }^{\circ} \mathrm{C}, 8 \mathrm{~h}$. Yield: $74 \%$ $\mathbf{( 4 a / 5 a / i s o m e r s ~}=74 / 16 / 9) . \quad 2(100 \mu 1,1.77 \mathrm{mmol}), \mathbf{3 a}(170 \mu 1,1.48 \mathrm{mmol}), \mathbf{1}(19.7 \mathrm{mg}, 0.058 \mathrm{mmol})$, toluene $(2 \mathrm{ml}), 50{ }^{\circ} \mathrm{C}, 4 \mathrm{~h} . \quad$ Yield: $65 \%(\mathbf{4 a} / \mathbf{5 a} /$ isomers $=60 / 23 / 17) . \quad \mathbf{2}(100 \mu 1,0.88 \mathrm{mmol}), \mathbf{3 a}(85$ $\mu 1,0.74 \mathrm{mmol}), 1(50.4 \mathrm{mg}, 0.149 \mathrm{mmol})$, toluene $(1 \mathrm{ml}), 50{ }^{\circ} \mathrm{C}, 3 \mathrm{~h}$. Yield: $61 \%(\mathbf{4 a} / \mathbf{5 a} /$ isomers $=$ 43/33/24). $\quad 2$ (200 $\mu 1,1.77 \mathrm{mmol}), 3 \mathbf{a}(170 \mu 1,1.48 \mathrm{mmol}), \mathbf{1}(2.61 \mathrm{mg}, 0.0077 \mathrm{mmol})$, toluene (2 ml), $50{ }^{\circ} \mathrm{C}, 11$ h. Yield: $39 \%(\mathbf{4 a} / \mathbf{5 a} /$ isomers $=82 / 13 / 5)$.

\subsection{Hammett plot}

$2(200 \mu 1,1.77 \mathrm{mmol})$, styrene (3a) $(170 \mu 1,1.48 \mathrm{mmol}), 1$ (10.0 mg, $0.03 \mathrm{mmol})$, toluene (2 ml). Yield: $75 \%(\mathbf{4 a} / \mathbf{5 a} /$ isomers $=80 / 13 / 7)$. 
$2(200 \mu \mathrm{l}, 1.77 \mathrm{mmol})$, -methoxy styrene (3b) $(210 \mu \mathrm{l}, 1.48 \mathrm{mmol}), 1$ (10.0 mg, $0.03 \mathrm{mmol})$, toluene $(2 \mathrm{ml}), 50{ }^{\circ} \mathrm{C}, 8 \mathrm{~h}$. Yield: $49 \%(\mathbf{4 a} /$ isomer $=92 / 8)$. The products were purified by silicagel column chromatography with hexane as an eluent and were identified by NMR spectra. (E)-1-methoxy-4-(4,5-dimethyl-1,4-hexadienyl)benzene (4b): ${ }^{1} \mathrm{H}$ NMR (400 MHz, benzene- $d_{6}$, r.t.): $\delta$ $7.21\left(\mathrm{~d}, J=9.2 \mathrm{~Hz}, 2 \mathrm{H},-\mathrm{C}_{6} H_{4^{-}}\right), 6.76\left(\mathrm{~d}, J=11.4 \mathrm{~Hz}, 2 \mathrm{H},-\mathrm{C}_{6} H_{4^{-}}\right), 6.38(\mathrm{~d}, J=15.4 \mathrm{~Hz}, 1 \mathrm{H},=\mathrm{CH}-)$, $6.04(\mathrm{dt}, J=15.4 \mathrm{~Hz}, 6.9 \mathrm{~Hz}, 1 \mathrm{H},=\mathrm{CH}-), 3.28(\mathrm{~s}, 3 \mathrm{H},-\mathrm{OMe}), 2.89$ (d, $\left.J=6.8 \mathrm{~Hz}, 2 \mathrm{H},-\mathrm{CH}_{2^{-}}\right), 1.68(\mathrm{~s}$, $6 \mathrm{H},-\mathrm{Me}), 1.63(\mathrm{~s}, 3 \mathrm{H},-\mathrm{Me}) .{ }^{13} \mathrm{C}\left\{{ }^{1} \mathrm{H}\right\}$ NMR (100 MHz, benzene-d $d_{6}$, r.t.): $\delta 159.31$ (s), 130.01 (s), 127.29 (s), 126.33 (s), 114.24 (s), 54.70 (s), 38.39 (s), 20.68 (s), 20.29 (s), 18.59 (s). GC-MS: m/z = $216\left(\mathrm{M}^{+}\right)$.

$2(200 \mu 1,1.77 \mathrm{mmol})$ p-methylstyrene (3c) (195 $\mu 1,1.48 \mathrm{mmol}), 1$ (10.0 mg, $0.03 \mathrm{mmol})$, toluene $(2 \mathrm{ml})$, Yield: $51 \%(\mathbf{4 c / 5} \mathbf{c} /$ isomers $=90 / 2 / 8)$. These products were purified by silicagel column chromatography with hexane as an eluent and were identified by NMR spectra. (E)-1-methyl-4-(4,5-dimethyl-1,4-hexadienyl)benzene (4c). ${ }^{1} \mathrm{H}$ NMR (400 MHz, benzene- $d_{6}$, r.t.): $\delta$ $7.22\left(\mathrm{~d}, J=8 \mathrm{~Hz}, 2 \mathrm{H},-\mathrm{C}_{6} H_{4^{-}}\right), 6.95\left(\mathrm{~d}, J=8 \mathrm{~Hz}, 2 \mathrm{H},-\mathrm{C}_{6} H_{4^{-}}\right), 6.39$ (d, $\left.J=16 \mathrm{~Hz}, 1 \mathrm{H},=\mathrm{CH}-\right), 6.11$ (dt, $J=15 \mathrm{~Hz}, 6.9 \mathrm{~Hz}, 1 \mathrm{H},=\mathrm{CH}-), 2.87\left(\mathrm{~d}, J=6.8 \mathrm{~Hz}, 2 \mathrm{H},-\mathrm{CH}_{2}-\right), 2.10(\mathrm{~s}, 3 \mathrm{H},-M e), 1.65(\mathrm{~s}, 6 \mathrm{H},-M e)$, $1.62(\mathrm{~s}, 3 \mathrm{H},-\mathrm{Me}) .{ }^{13} \mathrm{C}\left\{{ }^{1} \mathrm{H}\right\} \mathrm{NMR}\left(400 \mathrm{MHz}\right.$, benzene- $d_{6}$, r.t.): $\delta 130.45$ (s), 129.44 (s), 127.56 (s),

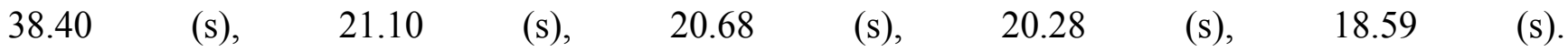
(E)-1-methyl-4-(4,5-dimethyl-2,4-hexadienyl)benzene (5c). ${ }^{1} \mathrm{H}$ NMR (400 MHz, benzene- $d_{6}$, r.t.): $\delta$ $7.10\left(\mathrm{~d}, J=8 \mathrm{~Hz}, 2 \mathrm{H},-\mathrm{C}_{6} H_{4^{-}}\right), 7.06\left(\mathrm{~d}, J=8 \mathrm{~Hz}, 2 \mathrm{H},-\mathrm{C}_{6} H_{4^{-}}\right), 6.67(\mathrm{~d}, J=15.5 \mathrm{~Hz}, 1 \mathrm{H},=\mathrm{CH}-), 5.75$ $(\mathrm{dt}, J=15.5 \mathrm{~Hz}, 6.8 \mathrm{~Hz}, 1 \mathrm{H},=\mathrm{CH}-), 3.39$ (d, $\left.J=7.5 \mathrm{~Hz}, 2 \mathrm{H},-\mathrm{CH}_{2}-\right), 2.13(\mathrm{~s}, 3 \mathrm{H},-\mathrm{Me}), 1.71(\mathrm{~s}, 6 \mathrm{H}$, $-M e), 1.62$ (s, 3H, $-M e)$.

$2(200 \mu 1,1.77 \mathrm{mmol}), p$-chlorostyrene (3d) (190 $\mu 1,1.48 \mathrm{mmol}), 1$ (10.0 mg, $0.03 \mathrm{mmol})$, toluene $(2 \mathrm{ml})$. Yield: $89 \%(\mathbf{4 d} / \mathbf{5 d} /$ isomers $=75 / 19 / 6)$. The products were purified by silicagel chromatography with hexane as an eluent and were identified by NMR spectra. (E)-1-chloro-4-(4,5-dimethyl-1,4-hexadienyl)benzene (4d). ${ }^{1} \mathrm{H}$ NMR (400 MHz, benzene- $d_{6}$, r.t.): $\delta$ $7.06\left(\mathrm{~d}, J=8.6 \mathrm{~Hz}, 2 \mathrm{H},-\mathrm{C}_{6} H_{4^{-}}\right), 6.89$ (d, $\left.J=8.6 \mathrm{~Hz}, 2 \mathrm{H},-\mathrm{C}_{6} H_{4^{-}}\right), 6.15(\mathrm{~d}, J=15.5 \mathrm{~Hz}, 1 \mathrm{H},=\mathrm{CH}-$ ), $5.94(\mathrm{dt}, J=16.0 \mathrm{~Hz}, 6.3 \mathrm{~Hz}, 1 \mathrm{H},=\mathrm{CH}), 2.79$ (d, $\left.J=6.3 \mathrm{~Hz}, 2 \mathrm{H},-\mathrm{CH}_{2^{-}}\right), 1.69$ (s, 6H, -Me), 1.62 (s, 3H, -Me). GC-MS: $\quad \mathrm{m} / \mathrm{z}=220\left(\mathrm{M}^{+}\right) . \quad(E)$-1-chloro-4-(4,5-dimethyl-2,4-hexadienyl)benzene (5d): ${ }^{1} \mathrm{H}$ NMR (400 MHz, benzene-d $d_{6}$, r.t.): $\delta 7.10$ (d, $J=9.2 \mathrm{~Hz}, 2 \mathrm{H},-\mathrm{C}_{6} H_{4^{-}}$), 6.80 (d, $J=8.6 \mathrm{~Hz}, 2 \mathrm{H}$, $\left.-\mathrm{C}_{6} H_{4^{-}}\right), 6.58(\mathrm{~d}, J=15.5 \mathrm{~Hz}, 1 \mathrm{H},=\mathrm{CH}-), 5.56(\mathrm{dt}, J=15.5 \mathrm{~Hz}, 7.4 \mathrm{~Hz}, 1 \mathrm{H},=\mathrm{CH}-)^{2}, 3.16(\mathrm{~d}, J=6.9 \mathrm{~Hz}$, $\left.2 \mathrm{H},-\mathrm{CH}_{2^{-}}\right), 1.69(\mathrm{~s}, 6 \mathrm{H},-\mathrm{Me}), 1.62(\mathrm{~s}, 3 \mathrm{H},-\mathrm{Me})$. GC-MS: $\mathrm{m} / \mathrm{z}=220\left(\mathrm{M}^{+}\right)$.

$2(200 \mu 1,1.77 \mathrm{mmol}), \quad p$-trifluoromethylstyrene (3e) $(325 \mu 1,1.01 \mathrm{mmol}), \mathbf{1} \quad$ (6.82 mg, 0.02 mmol), toluene $(2 \mathrm{ml})$, Yield: $74 \%(4 \mathbf{e} / \mathbf{5 e} /$ isomers $=85 / 12 / 3)$. The products were purified by silicagel chromatography with hexane as an eluent and were identified by NMR spectra. (E)-1-trifluoromethyl-4-(4,5-dimethyl-1,4-hexadienyl)benzene $\quad(4 \mathbf{e}): \quad{ }^{1} \mathrm{H} \quad \mathrm{NMR} \quad(400 \quad \mathrm{MHz}$, 
chloroform- $d$, r.t.): $\delta 7.51$ (d, $\left.J=8.6 \mathrm{~Hz}, 2 \mathrm{H},-\mathrm{C}_{6} H_{4^{-}}\right), 7.41$ (d, $\left.J=8.6 \mathrm{~Hz}, 2 \mathrm{H},-\mathrm{C}_{6} H_{4^{-}}\right), 6.36(\mathrm{~d}, J=$ $16.0 \mathrm{~Hz}, 1 \mathrm{H},=\mathrm{CH}-), 6.25(\mathrm{dt}, J=16.0 \mathrm{~Hz}, 6.3 \mathrm{~Hz}, 1 \mathrm{H},=\mathrm{CH}-), 2.93\left(\mathrm{~d}, J=6.3 \mathrm{~Hz}, 2 \mathrm{H},-\mathrm{CH}_{2^{-}}\right), 1.73(\mathrm{~s}$, $3 \mathrm{H},-M e), 1.70(\mathrm{~s}, 3 \mathrm{H},-M e), 1.64(\mathrm{~s}, 3 \mathrm{H},-M e) .{ }^{1} \mathrm{H}$ NMR $(400 \mathrm{MHz}$, benzene-d6, r.t.): $\delta 7.29(\mathrm{~d}, J=$ $\left.8.0 \mathrm{~Hz}, 2 \mathrm{H},-\mathrm{C}_{6} H_{4}\right), 6.96\left(\mathrm{~d}, J=8.0 \mathrm{~Hz}, 2 \mathrm{H}, \mathrm{C}_{6} H_{4}\right), 6.16(\mathrm{~d}, J=15.1 \mathrm{~Hz}, 1 \mathrm{H},=\mathrm{CH}-), 6.01(\mathrm{dt}, J=6.8$ $\mathrm{Hz}, 1 \mathrm{H},=\mathrm{CH}-), 2.78\left(\mathrm{~d}, J=6.8 \mathrm{~Hz}, 2 \mathrm{H},-\mathrm{CH}_{2^{-}}\right), 1.62(\mathrm{~s}, 9 \mathrm{H},-\mathrm{Me}) .{ }^{13} \mathrm{C}\left\{{ }^{1} \mathrm{H}\right\} \mathrm{NMR}(100 \mathrm{MHz}$, benzene- $d_{6}$, r.t.): $\delta 141.4$ (s), 131.5 (s), 129.0 (s), 126.4 (s), 124.6 (s), 38.3 (s), 20.7 (s), 20.3 (s), 18.5 (s): In this spectrum, the $\mathrm{CF}_{3}$ resonance was not observed. ${ }^{19} \mathrm{~F}$ NMR $\left(376 \mathrm{MHz}\right.$, benzene- $\left.d_{6}\right): \delta$ -61.9 (s). GC-MS: m/z = $254\left(\mathrm{M}^{+}\right) . \quad$ (E)-1-trifluoromethyl-4-(4,5-dimethyl-2,4-hexadienyl)benzene (5e): ${ }^{1} \mathrm{H}$ NMR (400 MHz, benzene- $d_{6}$, r.t.): $\delta 7.53$ (d, $\left.J=8 \mathrm{~Hz}, 2 \mathrm{H},-\mathrm{C}_{6} H_{4}-\right), 7.30(\mathrm{~d}, J=8.0 \mathrm{~Hz}, 2 \mathrm{H}$, $\left.-\mathrm{C}_{6} H_{4^{-}}\right), 6.61(\mathrm{~d}, J=14.9 \mathrm{~Hz}, 1 \mathrm{H},=\mathrm{C} H-), 5.65(\mathrm{dt}, J=15.5 \mathrm{~Hz}, 6.9 \mathrm{~Hz}, 1 \mathrm{H},=\mathrm{CH}-), 3.50(\mathrm{~d}, J=6.9 \mathrm{~Hz}$, $\left.2 \mathrm{H},-\mathrm{CH}_{2^{-}}\right), 1.81(\mathrm{~s}, 3 \mathrm{H},-\mathrm{Me}), 1.77(\mathrm{~s}, 3 \mathrm{H},-\mathrm{Me}), 1.74(\mathrm{~s}, 3 \mathrm{H},-\mathrm{Me}) .{ }^{13} \mathrm{C}\left\{{ }^{1} \mathrm{H}\right\} \mathrm{NMR}(100 \mathrm{MHz}$, benzene- $d_{6}$, r.t.): $\delta 145.5$ (s), 131.7 (s), 129.1 (s), 126.0 (s), 125.1 (s), 39.6 (s), 21.6 (s), 20.2 (s), 14.6 (s). ${ }^{19}$ F NMR (376 MHz, benzene- $\left.d_{6}\right): \delta-61.8(\mathrm{~s}) . \quad$ GC-MS: $\mathrm{m} / \mathrm{z}=254\left(\mathrm{M}^{+}\right)$.

$2(200 \mu 1,1.77 \mathrm{mmol}), p$-nitrostyrene (3f) $(235 \mu 1,1.48 \mathrm{mmol}), \mathbf{1}$ (10.0 mg, $0.03 \mathrm{mmol})$, toluene $(2 \mathrm{ml})$. Yield: $87 \%(\mathbf{4 f} /$ isomers $=85 / 15)$. The product was purified by silicagel column chromatography with hexane as an eluent and were identified by NMR spectra. (E)-1-nitro-4-(4,5-dimethyl-1,4-hexadienyl)benzene (4f): ${ }^{1} \mathrm{H}$ NMR (400 MHz, benzene- $d_{6}$, r.t.): $\delta$ $7.83\left(\mathrm{~d}, J=9.2 \mathrm{~Hz}, 2 \mathrm{H},-\mathrm{C}_{6} H_{4}-\right), 6.79\left(\mathrm{~d}, J=8.6 \mathrm{~Hz}, 2 \mathrm{H},-\mathrm{C}_{6} H_{4^{-}}\right), 6.06(\mathrm{~d}, J=16 \mathrm{~Hz}, 1 \mathrm{H},=\mathrm{CH}-), 5.98$ $(\mathrm{dt}, J=16 \mathrm{~Hz}, 6.3 \mathrm{~Hz}, 1 \mathrm{H},=\mathrm{CH}-), 2.76\left(\mathrm{~d}, J=6.3 \mathrm{~Hz}, 2 \mathrm{H},=\mathrm{CH}_{2^{-}}\right), 1.61(\mathrm{~m}, 9 \mathrm{H},-\mathrm{Me}) .{ }^{13} \mathrm{C}\left\{{ }^{1} \mathrm{H}\right\}$ NMR (100 MHz, benzene- $d_{6}$, r.t.): $\delta 133.67$ (s), 128.38 (s), 126.39 (s), 123.88 (s), 38.36 (s), 20.64 (s), 20.27 (s), 18.58. GC-MS: $\mathrm{m} / \mathrm{z}=231\left(\mathrm{M}^{+}\right)$.

The observed initial formation rate $r_{\text {int }}\left(\mathrm{M} \mathrm{s}^{-1}\right)$ of 4 (the number in parentheses indicates concentrations (M) of 1); 4a: $1.80 \times 10^{-7}(0.0125)$, 4b: $1.22 \times 10^{-7}(0.0124), 4 \mathbf{c}: 1.24 \times 10^{-7}(0.0124)$, 4d: $2.48 \times 10^{-7}(0.0124), 4 \mathrm{e}: 1.16 \times 10^{-7}(0.0080)$, and $4 \mathbf{f}: 4.06 \times 10^{-7}(0.0122)$.

\subsection{Isotopic labelling experiments}

(Method A): $2(200 \mu 1,1.77 \mathrm{mmol})$ and styrene- $\beta, \beta^{\prime}-d_{2}\left(\mathbf{3 a}-d_{2}\right)(175 \mu 1,1.48 \mathrm{mmol}), 1$ (10.01 $\mathrm{mg}, 0.030 \mathrm{mmol})$, toluene $(2 \mathrm{ml}), 40{ }^{\circ} \mathrm{C}, 8 \mathrm{~h}$. Yield: $79 \%\left(\mathbf{4 a}-d_{2} / \mathbf{5 a}-d_{2} /\right.$ isomers $\left.=78 / 14 / 8\right)$. These products were purified by silicagel column chromatography with hexane as an eluent and were identified by NMR spectra. (E)-2,3,6-triduterium-(4,5-dimethyl-1,4-hexadienyl)benzene $\left(\mathbf{4 a -} d_{2}\right):{ }^{1} \mathrm{H}$ NMR (400 MHz, benzene- $d_{6}$, r.t.): $\delta 7.25\left(\mathrm{~d}, J=7.4 \mathrm{~Hz}, 2 \mathrm{H},-\mathrm{C}_{6} H_{4^{-}}\right), 7.11\left(\mathrm{~d}, J=8 \mathrm{~Hz}, 2 \mathrm{H},-\mathrm{C}_{6} H_{4^{-}}\right)$, $7.02\left(\mathrm{t}, J=5.2 \mathrm{~Hz}, 1 \mathrm{H},-\mathrm{C}_{6} H_{4^{-}}\right), 6.37$ (d, $\left.J=12 \mathrm{~Hz}, 1 \mathrm{H},=\mathrm{CH}-\right), 6.0(\mathrm{dt}, J=16 \mathrm{~Hz}, 6.9 \mathrm{~Hz}, 0.33 \mathrm{H}$, $=\mathrm{CH}-), 2.83\left(\mathrm{~m}, 1.58 \mathrm{H},=\mathrm{CH}_{2^{-}}\right), 1.64(\mathrm{~s}, 2.69 \mathrm{H},-\mathrm{Me}), 1.62(\mathrm{~s}, 3 \mathrm{H},-\mathrm{Me}) .{ }^{2} \mathrm{H} \mathrm{NMR}(61 \mathrm{MHz}$, benzene, r.t.): $\delta 6.12(\mathrm{~m}, 0.67 \mathrm{D}), 2.79(\mathrm{~m}, 0.42 \mathrm{D}), 1.61$ (m, 0.71D). GC-MS: $\mathrm{m} / \mathrm{z}=188 \quad\left(\mathrm{M}^{+}\right)$. 
(E)-1,2,3,6-tetraduterium-(4,5-dimethyl-2,4-hexadienyl)benzene (5a- $\left.d_{2}\right):{ }^{2} \mathrm{H}$ NMR (61 MHz, benzene, r.t.): $\delta 6.62(\mathrm{~m}, 0.12 \mathrm{D}), 5.69(\mathrm{~m}, 0.62 \mathrm{D}), 3.32(\mathrm{~m}, 0.25 \mathrm{D}), 1.63-1.69$ (m, 0.90D). (Method B): In an NMR tube, dibenzyl $(3.44 \mathrm{mg}, 0.0188 \mathrm{mmol})$ was dissolved in benzene- $d_{6}(300 \mu \mathrm{l})$. Then, $2(16.6 \mu \mathrm{l}$, $0.148 \mathrm{mmol}), \mathbf{3 a}(8.4 \mu \mathrm{l}, 0.073 \mathrm{mmol})$ and $\mathbf{3 a}-d_{2}(8.8 \mu \mathrm{l}, 0.073 \mathrm{mmol})$ were added into the solution. After measurement the first NMR spectra, $1(1.03 \mathrm{mg}, 0.00305 \mathrm{mmol})$ was added and then benzene- $d_{6}$ was added to adjust the volume being $0.600 \mathrm{ml}$. The NMR tube was heated at $40{ }^{\circ} \mathrm{C}$ for the catalysis.

\subsection{Eyring plot}

The reactions were carried out under the following conditions and the reaction was monitored by GLC. Conditions: $2(200 \mu \mathrm{l}, 1.77 \mathrm{mmol}), 3 \mathbf{a}(170 \mu \mathrm{l}, 1.48 \mathrm{mmol})$, toluene $(2.00 \mathrm{ml}), 1$ (10 mg, 0.03 mmol), dibenzyl as an internal standard $(67 \mathrm{mg}, 0.37 \mathrm{mmol})$. The reaction was perfomed at $41{ }^{\circ} \mathrm{C}, 46$ ${ }^{\circ} \mathrm{C}, 49{ }^{\circ} \mathrm{C}, 55^{\circ} \mathrm{C}, 59{ }^{\circ} \mathrm{C}, 65^{\circ} \mathrm{C}$, or $71{ }^{\circ} \mathrm{C}$.

\subsection{Reaction of 6 with methyl acrylate}

Complex $6(7.1 \mathrm{mg}, 0.023 \mathrm{mmol})$ and triphenylmethane as an internal standard $(7.1 \mathrm{mg}, 0.029$ mmol) were placed in an NMR tube and toluene- $d_{8}(600 \mu l)$ was introduced. At $-60{ }^{\circ} \mathrm{C}$, methyl acrylate $(2.2 \mu \mathrm{l}, 0.025 \mathrm{mmol})$ was added by a hypodermic syringe and the reaction mixture was measured by NMR. 7: ${ }^{1} \mathrm{H}$ NMR (400 MHz, toluene- $\left.d_{8},-60{ }^{\circ} \mathrm{C}\right): \delta 4.94-4.91(\mathrm{~m}, 1 \mathrm{H}, 3-$ or 2-CH), 4.89-4.82 (m, 1H, 2- or 3-CH), 3.75 (m, 1H, COD), 3.6 (br, 1H, COD), 3.44 (s, 3H, Me), 3.4 (br. m, 2H, COD), 2.3 (br. m, 1H, COD), 2.2-2.1 (br, 2H, COD), 1.7-1.6 (br. m, 2H, COD), 1.41 (m, 1H, 4- or 1-exo-CH), 1.3 (br. m, 2H, COD), 0.97-0.95 (m, 1H, COD), 0.95 (m, 1H, 1- or 4-exo-CH), 0.43 (m, $1 \mathrm{H}, 4$ - or 1-endo- $\mathrm{CH}),-0.72(\mathrm{~m}, 1 \mathrm{H}, 1$ - or 4-endo- $\mathrm{CH})$. The alkenyl protons of coordinating methyl acrylate probably overlapped with the COD protons. The NMR data for $\mathbf{8}$ was reported elsewhere [8].

\subsection{Reaction of 1 with 2,3-dimethylbuta-1,3-diene and styrene}

Complex $1(10.1 \mathrm{mg}, 0.030 \mathrm{mmol})$ was placed in an NMR tube to which toluene- $d_{8}(600 \mu \mathrm{l})$ was added. 2,3-Dimethylbuta-1,3-diene $(3.4 \mu \mathrm{l}, 0.030 \mathrm{mmol})$ was added to the solution and the NMR spectra were measured at $-50{ }^{\circ} \mathrm{C}$ and $-30{ }^{\circ} \mathrm{C}$. Then, styrene $(3.4 \mu 1,0.030 \mathrm{mmol})$ was added and the NMR spectra were measured at the temperature range of -80 to $+10{ }^{\circ} \mathrm{C}$. The ${ }^{1} \mathrm{H}$ NMR spectrum of the final major product $\mathbf{D}$ was as follows: ${ }^{1} \mathrm{H} \mathrm{NMR}\left(400 \mathrm{MHz}\right.$, toluene- $\left.d_{8},-80{ }^{\circ} \mathrm{C}\right): \delta 7.5-7.0$ (overlapped, $P h$ ), 4.70 (br. d, $J=9 \mathrm{~Hz}, 1 \mathrm{H}, \mathrm{PhCH}=$ ), 4.61 (br. dd, $J=9,4 \mathrm{~Hz}, 1 \mathrm{H},=\mathrm{CHCH}_{2-}$ ), 3.9-3.8 
(br. m, 2H, COD), 2.9 (br. m, 1H, COD), 2.8-2.5 (br. m, 3H, COD), 2.58 (br. s, 1H, CHH), 2.46 (br.d, $J=4 \mathrm{~Hz}, 1 \mathrm{H}, \mathrm{CHH}$ ), 2.5-2.4 (br. m, 1H, COD), 2.2-1.2 (overlapped, COD), 1.67 (s, overlapped, Me), 1.32 (s, 3H, Me), 0.98 (br. m, 2H, COD), 0.85 (br. m, overlapped, 1H, COD), 0.83 (s, 3H, Me).

\subsection{DFT calculations}

The density functional theory (DFT) calculations were employed with long-range and dispersion corrected $\omega$ B97X-D functional [20]. The basis set was consisted of the Stuttgart-Dresden SDD effective core potential basis set on the Ru atom [21] and the 6-31G(d,p) basis sets on all other atoms [22]. Effect of benzene as a solvent was included in the calculations by using the Polarizable Continuum Model (PCM) using the integral equation formalism variant (IEFPCM) [23]. The optimised molecular structures were verified by vibrational analysis; equilibrium structures did not have imaginary frequencies and transition state structures had only one imaginary frequency corresponding to the reaction coordinate. Additionally, the intrinsic reaction coordinate (IRC) calculations $[24,25]$ were carried out to check whether the transition state leads to the reactant and the product, or not. Relative energies were corrected by adding the unscaled zero-point vibrational energy. All calculations were carried out using the Gaussian 09 program [26].

\section{Acknowledgements}

The numerical calculations were carried out on the TSUBAME2.5 supercomputer at the Tokyo Institute of Technology, Tokyo, Japan, and on the supercomputer at the Research Center for Computational Science, Okazaki, Japan. This work was financially supported by Japan Science and Technology Agency (JST), ACT-C.

\section{Notes and references}

$\uparrow$ Supporting information available: The detailed calculated structures for the hydride transfer steps, cartesian coordinates and electronic energies for A, TS1, B, TS2, INT1, TS3, C, TS4, INT2, TS5, D and a TS for hydride transfer.

[1] (a) T. Kondo, Bull. Chem. Soc. Jpn. 84 (2011) 441. (b) N. Chatani, Chem. Rec. 8 (2008) 201. (c) C. Bruneau, P.H. Dixneuf, In Ruthenium Catalysts and Fine Chemistry; Springer: New York (2004) p 11. (d) B.M. Trost, F.D. Toste, A.B. Pinkerton, Chem. Rev. 101 (2001) 2067. 
[2] (a) D. Witternberg, Angew. Chem. 75 (1963) 1124. (b) A. Misono, Y. Uchida, T. Saito, K. Uchida, Bull. Chem. Soc. Jpn. 40 (1967) 1889. (c) G.A. Tolstikov, U.M. Dzhemilev, R.I. Khunutdinov, Z. Obshch. Khim. 45 (1975) 1322. (d) H. Singer, W. Umbach, M. Dohr, Synthesis (1971) 265. (e) H. Bönnemann, C. Grard, W. Kopp, W. Pump, K. Tanaka, G. Wilke, Pure Appl. Chem. 6 (1971) 265. (f) K.S. Feldman, K.C. Grega, J. Organomet. Chem. 381 (1990) 251.

[3] B. Moreau, J.Y. Wu, T. Ritter, Org. Lett. 11 (2008) 337.

[4] M. Arndt, M. Dindarogle, H.-G. Schmalz, G. Hilt, Org. Lett. 13 (2011) 6236.

[5] (a) H. Tsujita, Y. Ura, K. Wada, T. Kondo, T. Mitsudo, Chem. Commun. (2005) 5100. (b) H. Tsujita, Y. Ura, S. Matsuki, K. Wada, T. Kondo, T. Mitsudo, Angew. Chem. Int. Ed. 46 (2007) 5160. (c) M.-O. Simon, S. Darses, J. Org. Chem. 78 (2013) 9981.

[6] (a) B.M. Trost, K. Imi, I.W. Davies, J. Am. Chem. Soc. 117 (1995) 5371. (b) T. Sato, F. Kakiuchi, N. Chatani, S. Murai, Chem. Lett. (1998) 893.

[7] M. Hirano, Y. Sakate, N. Komine, S. Komiya, M. A. Bennett, Organometallics 28 (2009) 4902.

[8] M. Hirano, Y. Arai, Y. Hamamura, N. Komine, S. Komiya, Organometallics 31 (2012) 4006.

[9] Although these trends show the present system not to be a strict zero-order reactions, further set up of these catalytic conditions failed. Therefore we glance only overall nature of these kinetics.

[10] E.M. Simmons, J.F. Hartwig, Angew. Chem. Int. Ed. 51 (2012) 3066.

[11] M. Gómez-Gallego, M.A. Sierra, Chem. Rev. 111 (2011) 4857.

[12] M. Hirano, Y. Sakate, N. Komine, S. Komiya, X.-Q. Wang, M.A. Bennett, Organometallics 30 (2011) 768 .

[13] We tentatively assigned this product to be D. However, resonances for the COD ligand obscured and we could not rule out the isomerization to 1,3-COD.

[14] In the dynamic behavior of the putative species $\mathbf{A}$ interacted with the broadening of the free styrene resonances. This behavior is consistent with the rapid coordination/dissociation of styrene in $\mathbf{A}$.

[15] M. Hirano, T. Okamoto, N. Komine, S. Komiya, Organometallics 31 (2012) 4639.

[16] M. Hirano, T. Okamoto, N. Komine, S. Komiya, New J. Chem. 38 (2014) 5052.

[17] M. Hirano, T. Shibasaki, S. Komiya, M. A. Bennett, Organometallics 21 (2002) 5738.

[18] A.A. Chalmers, D.C. Liles, E. Meintjies, H.E. Oosthuizen, J.A. Pretorius, E. Singleton, J. Chem. Soc., Chem. Commun. (1985) 1340.

[19] D. Tanaka, S.P. Romeril, A.G. Myers, J. Am. Chem. Soc. 127 (2005) 10323.

[20] J.-D. Chai, M. Head-Gordon, Phys. Chem. Chem. Phys.10 (2008) 6615.

[21] (a) L. V. Szentpaly, P. Fuentealba, H. Preuss, H. Stoll, Chem. Phys. Lett. 93 (1982) 555. (b) M. Dolg, U. Wedig, H. Stoll, H. Preuss, J. Chem. Phys., 86 (1987) 866. (c) P. Schwerdtfeger, M. 
Dolg, W.H.E. Schwarz, G.A. Bowmaker, P.D.W. Boyd, J. Chem. Phys. 91 (1989) 1762.

[22] W.J. Hehre, L. Radom, P.V.R. Schleyer, J.A. Pople, In Ab Initio Molecular Orbital Theory, Wiley: New York (1986).

[23] As a review for PCM models, see: J. Tomasi, B. Mennucci, R. Cammi, Chem. Rev. 105 (2005) 2999.

[24] K. Fukui, J. Phys. Chem. 74 (1970) 4161.

[25] H.P. Hratchian, H.B. Schlegel, J. Chem. Theory Comput. 1 (2005) 61.

[26] M.J. Frisch, G.W. Trucks, H.B. Schlegel, G.E. Scuseria, M.A. Robb, J.R. Cheeseman, G. Scalmani, V. Barone, B. Mennucci, G.A. Petersson, H. Nakatsuji, M. Caricato, X. Li, H.P. Hratchian, A.F. Izmaylov, J. Bloino, G. Zheng, J.L. Sonnenberg, M. Hada, M. Ehara, K. Toyota, R. Fukuda, J. Hasegawa, M. Ishida, T. Nakajima, Y. Honda, O. Kitao, H. Nakai, T. Vreven, J. A. Montgomery, Jr., J.E. Peralta, F. Ogliaro, M. Bearpark, J.J. Heyd, E. Brothers, K.N. Kudin, V.N. Staroverov, R. Kobayashi, J. Normand, K. Raghavachari, A. Rendell, J.C. Burant, S.S. Iyengar, J. Tomasi, M. Cossi, N. Rega, J. M. Millam, M. Klene, J.E. Knox, J.B. Cross, V. Bakken, C. Adamo, J. Jaramillo, R. Gomperts, R.E. Stratmann, O. Yazyev, A.J. Austin, R. Cammi, C. Pomelli, J.W. Ochterski, R.L. Martin, K. Morokuma, V.G. Zakrzewski, G.A. Voth, P. Salvador, J.J. Dannenberg, S. Dapprich, A.D. Daniels, Ö. Farkas, J.B. Foresman, J.V. Ortiz, J. Cioslowski, D.J. Fox, Gaussian 09, Revision D.01, Gaussian, Inc., Wallingford CT (2009). 


\section{Graphical Abstract}

The mechanistic studies for linear cross-dimerization between 2,3-dimethylbuta-1,3-diene and styrene by a $\mathrm{Ru}(0)$ complex are performed both by kinetic and computational studies, and these results support the oxidative coupling mechanism.

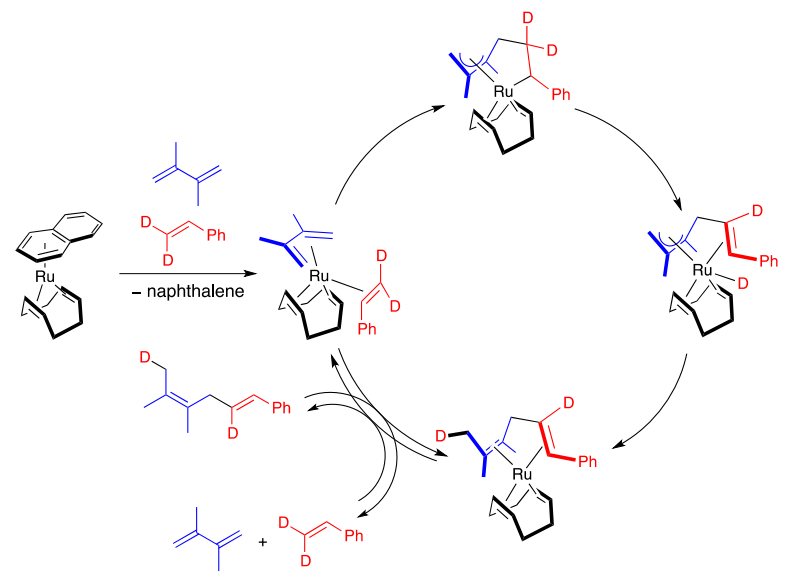

